Portland State University

PDXScholar

Anthropology Faculty Publications and

Presentations

Anthropology

Summer 2018

\title{
The Galleon's Final Journey: Accounts of Ship, Crew, and Passengers in the Colonial Archives
}

\author{
Cameron La Follette \\ Oregon Coast Alliance \\ Douglas Deur \\ Portland State University, deur@pdx.edu \\ Esther González
}

Follow this and additional works at: https://pdxscholar.library.pdx.edu/anth_fac

Part of the Archaeological Anthropology Commons, and the Biological and Physical Anthropology Commons

Let us know how access to this document benefits you.

\section{Citation Details}

Cameron La Follette, Douglas Deur, \& Esther González. (2018). The Galleon's Final Journey: Accounts of Ship, Crew, and Passengers in the Colonial Archives. Oregon Historical Quarterly, 119(2), 210-249.

This Article is brought to you for free and open access. It has been accepted for inclusion in Anthropology Faculty Publications and Presentations by an authorized administrator of PDXScholar. Please contact us if we can make this document more accessible: pdxscholar@pdx.edu. 


\section{The Galleon's Final Journey}

Accounts of Ship, Crew, and Passengers in the Colonial Archives

CAMERON LA FOLLETTE AND DOUGLAS DEUR, WITH ARCHIVAL RESEARCHER ESTHER GONZÁLEZ

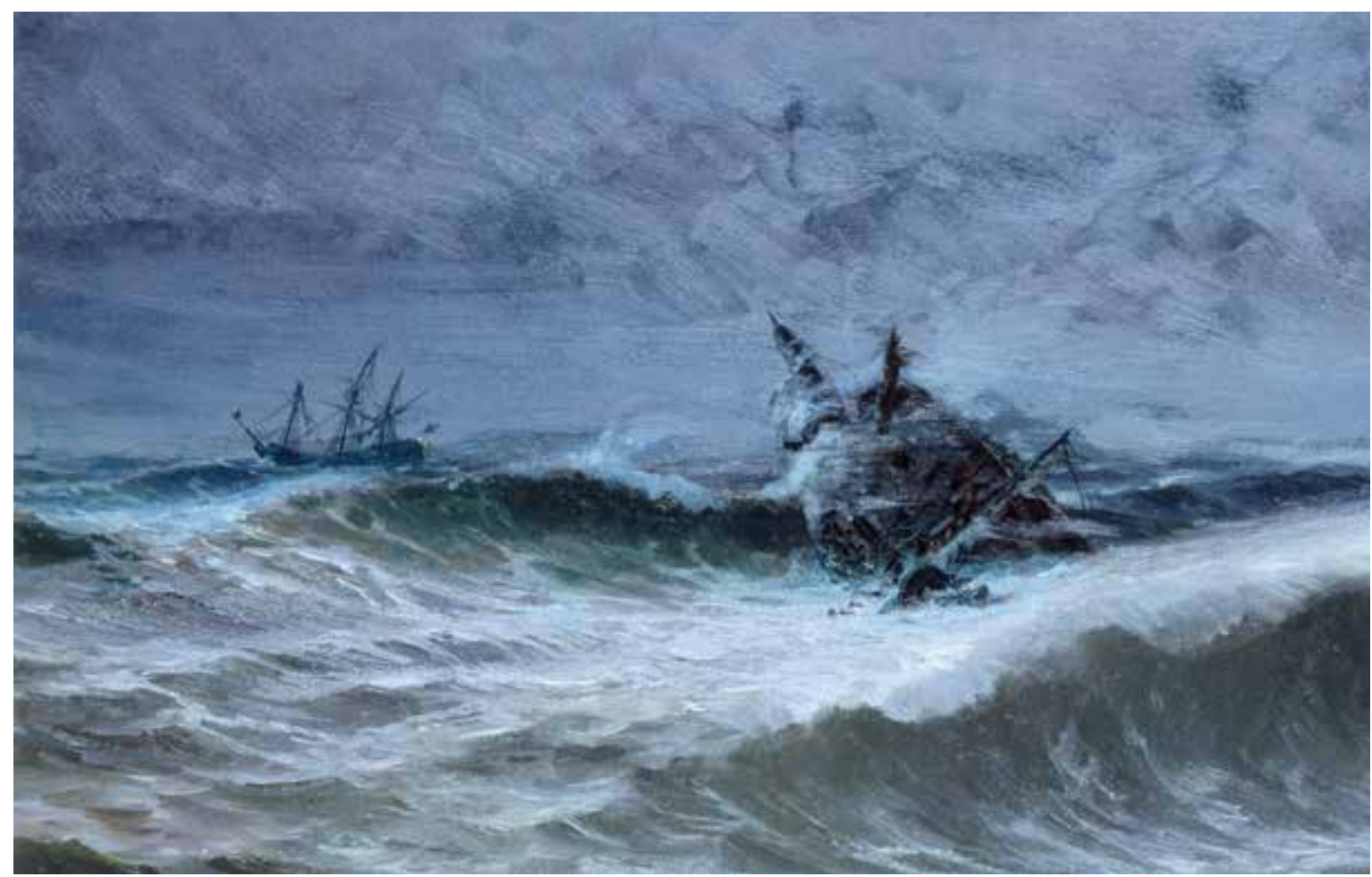

MANILA GALLEONS and other Spanish galleons were large and robust but vulnerable to tempestuous and rough seas. This painting by Tom Lovell depicts the destruction of Spain's Treasure Fleet of 1715 in a hurricane off the cost of central Florida. Spanish colonial records 
THE STORY OF THE LARGE SHIP wrecked on Nehalem Spit involves several interconnected mysteries. If the archeological team's determination that the Santo Cristo de Burgos is most likely that ship is correct, then archival research is essential to illuminating the ship's story while also correcting long-standing misconceptions about its fate that are deeply embedded in a smattering of secondary sources.

We began by also hoping to learn about the history, crew, and passengers of the San Francisco Xavier - the earlier favored candidate for the Nehalem wreck. The San Francisco Xavier vanished without a trace in 1705. Its captain was Don Santiago de Zabalburu y de Balenchana, brother of the Spanish Governor General of the Philippines, Don Domingo de Zabalburu y de Balenchana. Don Santiago de Zabalburu was a Basque nobleman from Gordejuela. According to his brother's application to become a member of the Knights of Santiago, the father of both was Domingo de Zabalburu, Mayor of the Valley of Gordejuela (1694) and armed knight. Their mother was Isabel Balenchana y Echabarri, whose father had been mayor of the same valley in $1665 .{ }^{1}$ Don Santiago de Zabalburu, younger than his brother the governor, was born in

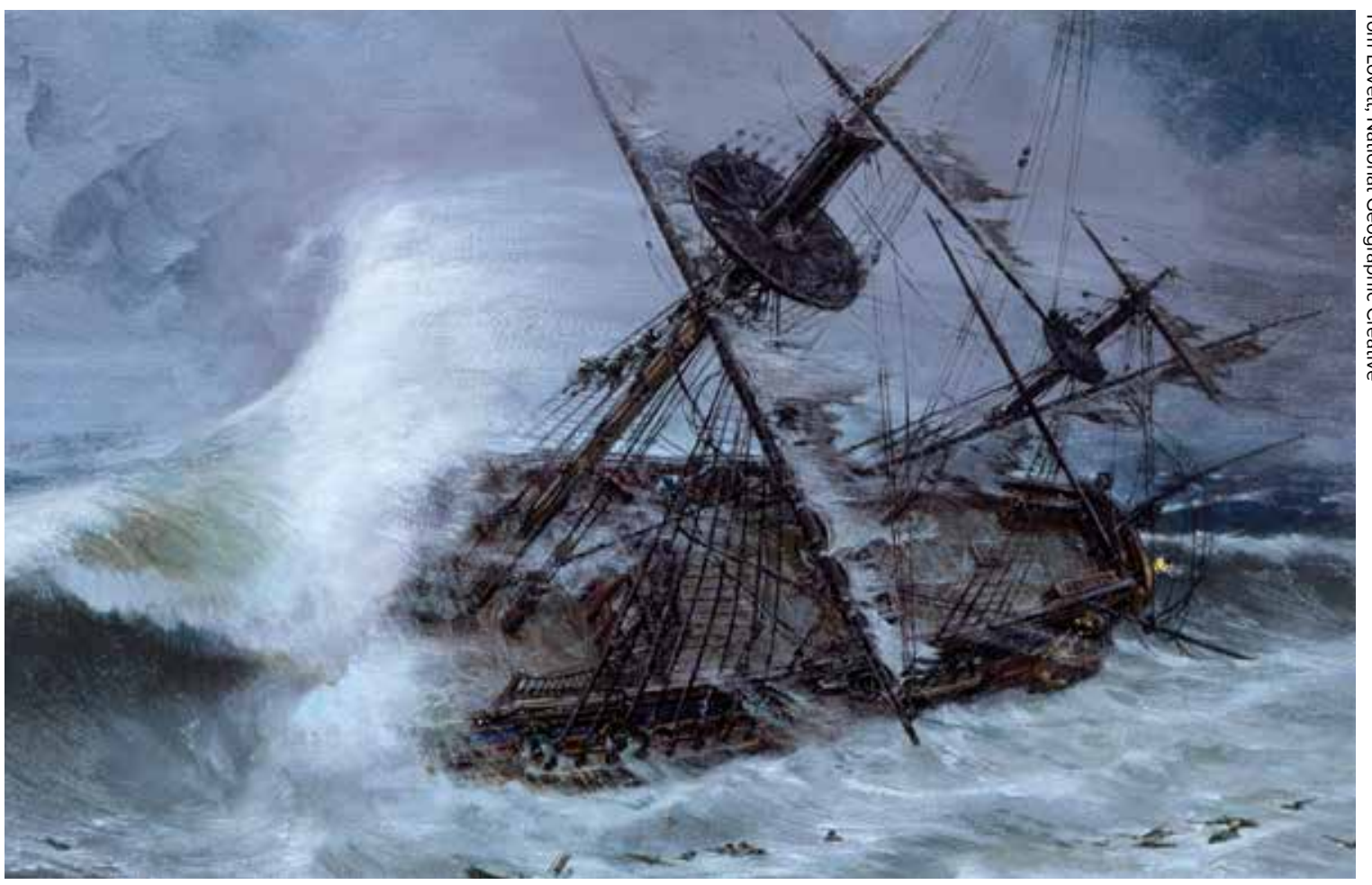

indicate that the Santo Cristo de Burgos, likely Oregon's galleon, left the Philippines late in the season without complete supplies and crew. This probably contributed to the ship's vulnerability and also increased the likelihood that it encountered winter cyclones on the Northwest coast. 
$1675 .{ }^{2}$ Thus, at the time of his death in the wreck of the San Francisco Xavier, wherever it took place, de Zabalburu was about thirty years old.

As an official put it a few years after the San Francisco's loss: "Nothing is known of its fate; not a fragment, no object whatever, large or small, has ever been found to serve as evidence or support for even a conjecture as to its fate, whether it was shattered on some unknown rock or was swallowed by the waves, crew and all - commander, seamen, and passengers, among whom were whole families of high rank. The ocean has kept the secret of

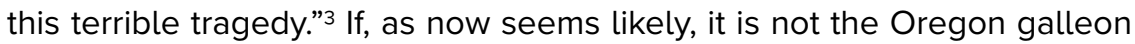
wreck, that ship has still never been found. And, except for the name and a bit of information about its captain, we were unable to locate anything like the rich archival documentation of the Santo Cristo de Burgos. The Santo Cristo de Burgos drew together a multiethnic, multilingual crew of Spanish, Spanish Basque, Philippine, Mexican, and possibly African men in the most sprawling global trade network of their day. Their fate probably resulted largely from winter storms blowing them off course, but archival research revealed another relevant factor: the Santo Cristo de Burgos departed the Philippines hastily in the summer of 1693 , leaving highly necessary crew and supplies behind, for complex reasons described below. This lack of skilled men and critical supplies may well have weakened the vessel's resilience in the face of severe weather and a long, arduous voyage. The wreck survivors were key participants in arguably the first Native-European contact on what is now the coast of Oregon, before disappearing into the state's cultural lore with few clear traces. Descendants of one or two of these men may have been key historical figures in the history of later relationships between Indigenous people and Euro-American explorers and settlers.

\section{THE SANTO CRISTO DE BURGOS: THE REPORTED HISTORY}

This research is a corrective, in many respects, for the reported history of the Santo Cristo de Burgos's disappearance in 1693, which has been obscured by a persistent, lurid fable. For decades, writers and historians repeated an account that this galleon had burned in the Marianas Islands, and a handful of the crew survived by cannibalism. This account was subsequently repeated in later research documents and books, without further examination.

This fable must be investigated, and dispelled, if we are to reconcile recent archaeological findings with the available archival record. ${ }^{4}$ There are two parts to this long-standing description of the Santo Cristo's fate: that it burned in the Marianas Islands; and that a few crew members escaped in a small boat, and two survived the ordeal by cannibalism upon their comrades. The two strands of this tale do not stem from the same sources. William Lytle Schurz, in his 1939 seminal account of the Manila galleon trade, first 
combined them, and researchers ever since have cited his account as the story of the galleon's demise during its fateful 1693 voyage. Schurz wrote:

She [the Santo Cristo de Burgos of 1693] suffered that most terrible of fates burning in the open sea - for pieces of charred wood, such as was used in the construction of the galleons, were later picked up on the beaches of the Ladrones [Marianas]. Her fate was eventually learned from two men picked up long after near the town of Binangonan de Lampon. In the boat in which they had managed to reach the Philippines was the corpse of a dead companion. One of the two survivors had gone stark mad from his sufferings. Before the burning galleon had foundered six men had put off from her side in an open boat and headed westward. After three weeks their food gave out and two of the starving men slid over the gunwales into the sea. Those who were left at last ... decided to draw lots as to which of the four should be eaten by the rest. One of the three preferred to starve rather than turn cannibal. It was only the last two who survived these horrible experiences, one without his reason, the other broken by his sufferings and long under the shadow of the Church for having partaken of human flesh. ${ }^{5}$

Despite these assertions, there was no direct proof that the Santo Cristo burned. Our investigation of contemporary and near-contemporary sources (as discussed here) indicates only suspicion that the ship might have burned, based on indirect evidence.

The origins of Schurz's account seem tied to a court case related to the ship. Because the Santo Cristo failed to reach Acapulco or any other known port in its 1693 voyage, the traders of Manila brought legal proceedings in the Royal Court of Manila to determine, if possible, what had happened. Some witnesses discussed the likelihood of the galleon's being overloaded with trading goods: "In the year [16]92 the galleon Santo Cristo docked in the harbor of San Miguel de Quipaio, of those islands, and in [16]93 set sail from there again, and since then has not been seen... There was also an element of hearsay to the report of the loss of the ship, attributing it to greed leading to overloading, as the Santo Cristo had not returned, nor anyone from it who could have confirmed this." 6

At least one witness at the court proceedings, Maestro de Campo (chief of staff) Tomás de Endaya, thought the ship must have burned. Endaya was a critical overseer and participant in the Santo Cristo's story at several junctures, so it is important for us to consider his history and reputation more closely. Endaya was probably Basque, almost certainly from the small coastal town of Orio in Gipuzkoa (Vizcaya), home to many members of the Endaya family from the fifteenth century on, and an important shipbuilding and whaling center from the sixteenth to eighteenth centuries. ${ }^{7}$ Endaya ultimately became prominent in the Spanish colony of the Philippines as a shipbuilder and overseer of the galleon industry. In that position, the original Spanish records indicate, he "taught the 
Indians the art of shipbuilding," among many other duties. ${ }^{8}$ Several Philippine Native peoples participated in, and built ships for, the vigorous regional trade with Southeast Asia, including China, Thailand, and Vietnam, before European arrival in the mid sixteenth century. ${ }^{9}$ It is therefore likely that Endaya's duties included teaching Philippine workers European ship-construction methods, especially the procedures of the galleon-building industry.

Endaya was controversial for aggregating power and influence to himself and his friends through a variety of government positions. Upper echelon Spanish officials in the Philippines often complained of Endaya and others like him:

The third line of men inhabiting these islands are soldiers .... of very humble and poor birth ... all aspiring to the rank of Governor ... to which end, they use all the means that can promote them, not omitting the most illicit..... Of all those mentioned above, the first and most important is one who passes for a native of Vizcaya, called Tomás de Endaya, who having come to these islands like all of them, without esteem and means, has sought out the Governors of his time to cultivate them, coming to dominate the territory, so that his rule is now absolute, and he has totally intimidated the locals [he has removed appointed civil servants and replaced them with his followers, so that] he has sown great animosity and bad will, and is abhorred even by his greatest friends, who attend him only for his great power and authority, which he applies in all estates, secular and ecclesiastical; everything is very easy for him with the power of Maestro de Campo. ${ }^{10}$

Despite having evidently made enemies in some quarters, as might be expected, Endaya's undeniable expertise was crucially valuable to the Spanish in the Philippines, where he ensured the smooth workings of the Manila trade.

Endaya, in his testimony on the lost Santo Cristo, stated he was "in charge of His Majesty's factories and shipyards, by order of the higher government, due to the lack of masters in these factories." He expressed the belief the Santo Cristo most likely was lost by fire:

He [Endaya] states he knows that in the year 92 the galleon Santo Cristo de Burgos docked in the port of San Miguel de Quipaio, that in that year it sailed to Acapulco, and in order to send it again the next year, 93, from the same port of San Miguel, this witness went to take part in equipping and preparing the ship, and that it set sail again to date nothing is known for certain about its whereabouts, it is presumed lost in a fire, given the large amounts of charcoal seen in the years 95 and 96 on the beaches of the Mariana Islands, recognized as laguán, the main planks, and molave, used for treenails in the ships of these islands, taken to be pieces which escaped the fire, and because in the north of those islands they found a long, large spar with different iron rings, which could only be one of the yardarms or the foremast, of the type of ring which the witness usually installed on all the yardarms of the ships he equipped." 


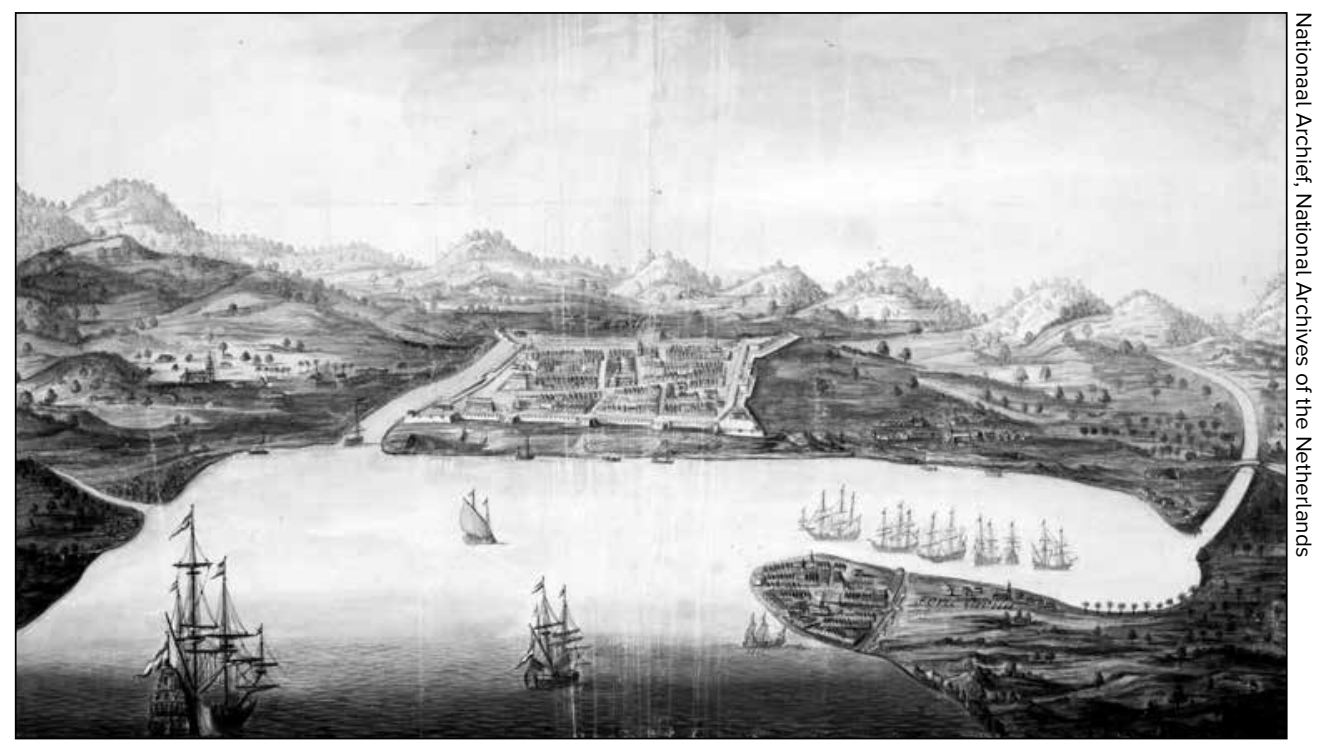

MANILA, IN THE PHILIPPINES, had a large, deep harbor. It had been a trading entrepôt for peoples of Southeast Asia, including China, Vietnam, and Malaysia, for hundreds of years before Spain colonized the region in the sixteenth century, transforming Manila into the hub of an intercontinental trade that exchanged South American silver for exquisite Asian goods shipped around the world. This painting, titled Birds eye view of Manila and by map maker Johannes Vingboons, depicts the harbor in about 1665.

A contemporary priestly chronicle noted that fragments of burned wood such as were used in galleon construction were found in the Marianas and sent to Manila by the interim Governor of the Marianas Islands, Don José Madrazo, after July 1696, when Madrazo assumed that position. ${ }^{12}$ Still, contemporaries seem to have only raised the possibility that the Santo Cristo de Burgos had burned, stating otherwise that in truth, nothing was known of its fate and no trace of the ship, its cargo, or any survivors had ever been found. As the chronicler summarized: "It [Santo Cristo de Burgos] remained at Solsogón in order to continue its voyage the year of 1693, as it did; but it not only failed to reach port, but was wrecked, without our gaining the least knowledge of the place where that occurred. ... Careful search was made for many years along the coasts of South America, and in other regions; but not the least news of the ship has been received."13

Additional sources of the time confirm the lack of certainty. Another priest, Fr. Pedro de Silva Alencastre, wrote in 1694, "In the same year [1692] the ship 'Santo Cristo' sailed for Acapulco, and had to come back to this port from the thirtieth degree of latitude. Then she sailed in July of [16]93, from the port of 
Naga; and up to the present time nothing is known about her fate."14 Treasury officials in Mexico in 1699 reported that they had no news about the Santo Cristo de Burgos, nor any who sailed in it, despite extensive searches. ${ }^{15}$ The preponderance of contemporary evidence suggests that the ship's fate was widely understood to be unknown and that the tale of the fire was largely speculative. Nevertheless, later publications on the Manila galleon trade have continued to cite Schurz's account as the sole evidence for this ship burning at sea, without recourse to independent research. ${ }^{16}$

There is similar history behind accounts suggesting that the few surviving crew of the Santo Cristo resorted to cannibalism. We can trace this narrative to a book of stories by an Irish-American settler from New York, Percy Hill, entitled Romantic episodes in old Manila: Church and state in the hands of a merry jester, Time. ${ }^{17}$ Beginning in 1907 , Hill ran a rice plantation in the Philippines and also researched and wrote accounts of early Spanish days in the islands. He initially published the book in Manila in 1925. His editor, Walter Robb, revised it from manuscripts and republished it in 1935 under a slightly different title. Both editions contain the same story of the Santo Cristo de Burgos of 1693. Robb wrote of Hill and his volume:

His avocation during the twenty-one years I have known him has been the reading of the mountainous chronicles of the Philippines friars (and Jesuits, of course), whence he gleaned the incidents recorded in his stories. . . . There [in Nueva Ecija], he has done his colossal reading of Philippine history ... and his memory is photographic; so much so that if parallel stories are extant in popular literature, Hill's diction approaches plagiarism; and in this volume I have had to relabel a yarn too blatantly partaking of Washington Irving in order to protect the author from himself. ... Our mutual desire to have the old Spanish friars better appreciated, and sometimes to smile at them, brings us together in this volume. Hill is not a very serious man ... he can still do full justice to a good bottle and a good book. ${ }^{18}$

Clearly, Hill's work, while informed by historical sources, was not understood by his contemporaries to be primarily historical in method or intent.

Hill recounts that two shipwrecked Spaniards were picked up by a Spanish trading goleta (schooner) near the town of Bingonan de Lampon and taken to Manila. One of the rescued sailors, named as Juan Valencia, said the Santo Cristo had foundered near the Marianas Islands not far from the Philippines. Four men survived in a small open boat for many days, at last deciding by lot which would be killed so the others could eat him and live. One survivor refused to become a cannibal and died of starvation. Of the other three, the lot fell on the youngest, and the other two killed him. Valencia recounted that he and his companion, the only two remaining men, ate the unfortunate victim; Valencia's portion had been to eat the feet. Hill's 
narrative concludes with a recounting of theological decision-making over which portions of the body contain the soul, and which do not - thus delimiting which consumption would be considered cannibalism by the Catholic Church. As Hill concludes: "At length the weighty decision was handed down, by a picked jury of the most learned. They agreed in the verdict that the soul of man extends only to the knees: man is required to kneel in prayer; ergo, that portion of the body that extends below the knees is a soulless appendage. The indictment against Valencia was accordingly stricken out. He was allowed to go free."19

We have found no Spanish documents of the period in Seville, Manila, or Mexico City, nor any published period documents of the Catholic Church or the Spanish colonial government in the Philippines, that verify, mention, or even allude to this account. The Archives of the Indies in Seville, furthermore, contain a complete crew list for the Santo Cristo's 1692 and 1693 voyages, reproduced below. There is no known crew member or passenger named Juan Valencia. We can only conclude that Hill's account is a satirical tale, written in part to shed humorous light on the Catholic Church in the Philippines during Spain's colonial rule.

\section{ARCHIVAL ACCOUNTS OF THE SANTO CRISTO DE BURGOS}

The Santo Cristo de Burgos was built and paid for in 1687-1688 in the Philippines, at the Royal shipyard of Solsogón, on the island of Bagatao at the mouth of Solsogón Bay. By the standards of the day, the ship appears to have stood apart: "The construction of the galleon Santo Cristo de Burgos at Solsogón has been done successfully, because of ... the quality of the wood used, it has been publicly acknowledged to be as one of the best built ships in these islands." 20

Several documents detail expenses and salaries involved during the ship's construction. Officials at the Royal Philippine treasury paid 250 pesos for fifty caulkers sent to the shipyards at Solsogón to work on the Santo Cristo, for example, and three hundred pesos for making hawsers, tackle, and other gear. The officials also disbursed ten thousand pesos to General Antonio Nieto, alcalde (mayor) of the province of Camarines, so the local overseer could pay the salaries and expenses of the Solsogón shipyard workers. ${ }^{21}$ The overall cost of the Santo Cristo was 65,243 pesos - which did not include the cost of 3,752 arrobas of iron for nails, because they were taken from a decommissioned galleon, the San Telmo, when it was broken up in the shipyard. The Santo Cristo also cost less to build than it might have because it "was built next to the mountains where the wood was cut." ${ }^{2}$ The ship was apparently fashioned of hardwoods from the unique virgin tropi- 
cal forest of that area, which attests to the quality of the construction while also potentially yielding archaeological clues for modern researchers. The galleon's sails were supported by three large masts, likely from tall, straight trees found in the same forests nearby.

\section{THE SANTO CRISTO'S SUCCESSFUL BUT TROUBLING 1690 TRIP}

The annual Manila galleon left the Philippines in about mid June, if possible (to avoid incoming stormy weather), and arrived in Acapulco five to seven or even eight months later, unless the voyage was especially propitious. The galleon left Acapulco for the return journey to the Philippines usually in February or March or, less frequently, April of the following year, arriving there after a journey of about three months.

The first trip relevant to the Santo Cristo's ultimate fate occurred in 1690-1691, when crew changes complicated its journey. On the eastward trip to Acapulco, which began in the summer of 1690, the ship was under the command of Francisco de Arcocha. But once it arrived, the Viceroy of New Spain, Gaspar de la Cerda Silva Sandoval y Mendoza, 8th Count of Galve (reigned 1688-1696), replaced Arcocha, as commander for the spring 1691 return to Manila with Don Bernardo Iñiguez del Bayo, the capitan de caballos (captain of the mounted cavalry) and a resident of Mexico. De la Cerda also replaced the sergeant major, boatswain, and maestre (master). These significant changes in top crew caused discontent and surprise both in New Spain and the Philippines:

The pretext for this was that there had been some news of Dutch or English ships being present in the Mar del Sur and it was presumed that the said General D. Francisco de Arcocha was not the appropriate person for what might occur in this mission, given his limited abilities. ... no attention was paid to the fact that this man had been appointed by the Governor of these islands [Philippines] . . . which caused considerable surprise, not only throughout New Spain but also in these islands. Sir, the consequences of these novelties is well known to be damaging for this trade. ${ }^{23}$

Political intrigue seems to have been behind the replacement of the commander. De la Cerda wanted a "gentleman of his household," Don Gabriel de Arnedo y Escudero, to be the Santo Cristo's Commander in 1689, but Arcocha only allowed him transit as a passenger. In his annoyance, the viceroy then removed Arcocha as commander. ${ }^{24}$ Subsequently, Arcocha complained of his dismissal and described his resulting destitution. ${ }^{25}$

Under the command of del Bayo, the Santo Cristo successfully returned to Manila in July 1691. The Santo Cristo carried the Crown subsidy of 131,504 pesos for maintenance of the Spanish colony in the Philippines, 24,028 pesos 
for the ecclesiastical stipend, and additional monies for colony residents. This annual financial transfer, as always, sustained the Philippine colony and its rather precarious trade-based economy: "As a result, the islands are in a satisfactory condition." ${ }^{26}$ Having just arrived back in the Philippines in July, the Santo Cristo did not make the Manila-Acapulco round trip beginning that same summer of 1691 , because the ship needed to be overhauled before undertaking the voyage again. ${ }^{27}$

\section{THE SANTO CRISTO'S DISASTROUS VOYAGE OF 1692}

In late June 1692, the Santo Cristo launched on another voyage, which ended in disaster, initiating a series of events that undermined crew morale and sealed its final fate as a shipwreck. That year, the galleon once again sailed from Manila, fully loaded with a diverse cargo of trade goods and bound for Acapulco. The value of its registered cargo (not including the extensive smuggled, unregistered goods commonly boarded onto Manila galleons) can be calculated at 256,666 pesos, based on the reported 3 percent almojarifazgo tax (galleon trade duties) of 7,700 pesos paid before departure. Del Bayo received a salary of 4,125 pesos. The Treasury also paid 14,524 pesos to an unnamed number of officials, thirty-six gunners, eighty seamen, twenty-four Spanish cabin boys, and sixty others on board the ship. There were also 149 pesos for a donation to the Royal Chapel. ${ }^{28}$ The first pilot of the 1692 trip was Juan Quintero, and there were two assistant pilots. Documents related to this voyage also name the other principal officials, including the master, boatswain, quartermaster's mate, chaplain, waterkeeper, notary, diver, steward, carpenter, shipwright, surgeon, and constable. ${ }^{29}$

The galleon departed from Cavite in the Manila region on June 30, 1692, and arrived near the Embocadero (the San Bernardino Strait) on September 14, later than was usual for galleon traffic. By that time of year, storms were increasingly likely on the North Pacific, threatening the safety of any ship attempting to cross. In a terrible gale on November 7, the Santo Cristo lost all three masts, and the damaged galleon limped back to Naga in Camarines for repairs, arriving on December 18 after a harrowing five-week makeshift journey. ${ }^{30}$ Del Bayo's report of the disaster, written on board the galleon in the Bay of Naga, described the storm:

Having reached the Marianas on 15 October at 24 degrees with unfavorable winds and much work... we encountered a northeasterly wind that sent us back to 30 degrees, in that position without squalls and with a choppy sea, we checked the foremast on the morning of 7 November and ordered it to be cut, this did not happen and it fell to the port side and broke the mainstay, and as the mainmast was also badly damaged, it fell onto the mizzen, and they were 
all smashed to pieces along with the main yardarm, topmasts, sails and all the rigging ... in 13 days we were able to rig up provisional sails and I decided to continue the voyage to New Spain, but with headwinds and having been forced South to 25 degrees, reluctantly I called a committee and we decided to land. ${ }^{31}$

The ship's hull was not damaged, but the galleon required extensive repairs to the masts and rigging.

It returned to the nearest place of safety, the Bay of Naga, rather than the main shipyard of Cavite. The question was whether repairs should be made there, with its limited shipbuilding facilities. If so, what should be done with the vast cargo of trade goods the galleon was carrying? A committee, formed to decide this question, rendered its decision in December 1692: "All the traders in this Committee having heard the agreements, they said that the trade goods in the galleon should be unloaded in the harbor in question and some huts should be made to hold all the cargo of the galleon, so that when the weather permitted the journey to New Spain, it could be loaded again" and that "one of the official judges of the Real Hacienda of these islands should leave for the Naga harbor to attend the unloading of the galleon, and make a record of all the goods, items, bundles and materials in the galleon." ${ }^{2}$ Unfortunately, only the document ordering the checklist to be made, but not the actual inventory of the Santo Cristo's cargo, is in the archival records.

As a result of the unscheduled return to port, no Manila galleon reached Acapulco in 1692-1693, causing destitution in the Philippine colony. The Spanish administration, as customary, conducted a detailed investigation into the causes of the arribada (return to port), including examination of named witnesses, all of which was faithfully recorded in official documents. The investigation reports many details of the ill-fated journey: "On November 7 at 30 degrees (latitude), the ship was demasted of three masts: main, fore and mizzen and ... a meeting was held to decide whether the journey should continue or not. The General wanted to continue the journey because the ship 'was neither leaking nor at risk' but everyone else, with the pilot leading, was opposed to sailing any further. They wanted to go into shore 'because there was no other choice for the ship with so few sails' and they would not reach the Straits of San Bernardino." The council making the decision consisted of the general, first pilot, assistant pilot, captains, boatswain, shipwright, and other officers. ${ }^{33}$

The investigation determined that the mast-hole of the foremast had been badly constructed and that the sails were too large for the mast and rigging. Del Bayo placed most of the blame on pilot Juan Quintero, accusing him of being inept and inebriated, in addition to changing the route inappropriately and cautioning the commander to turn back rather than try to sail through the Straits of San Bernardino. Officials then examined Quintero - a forty-two- 


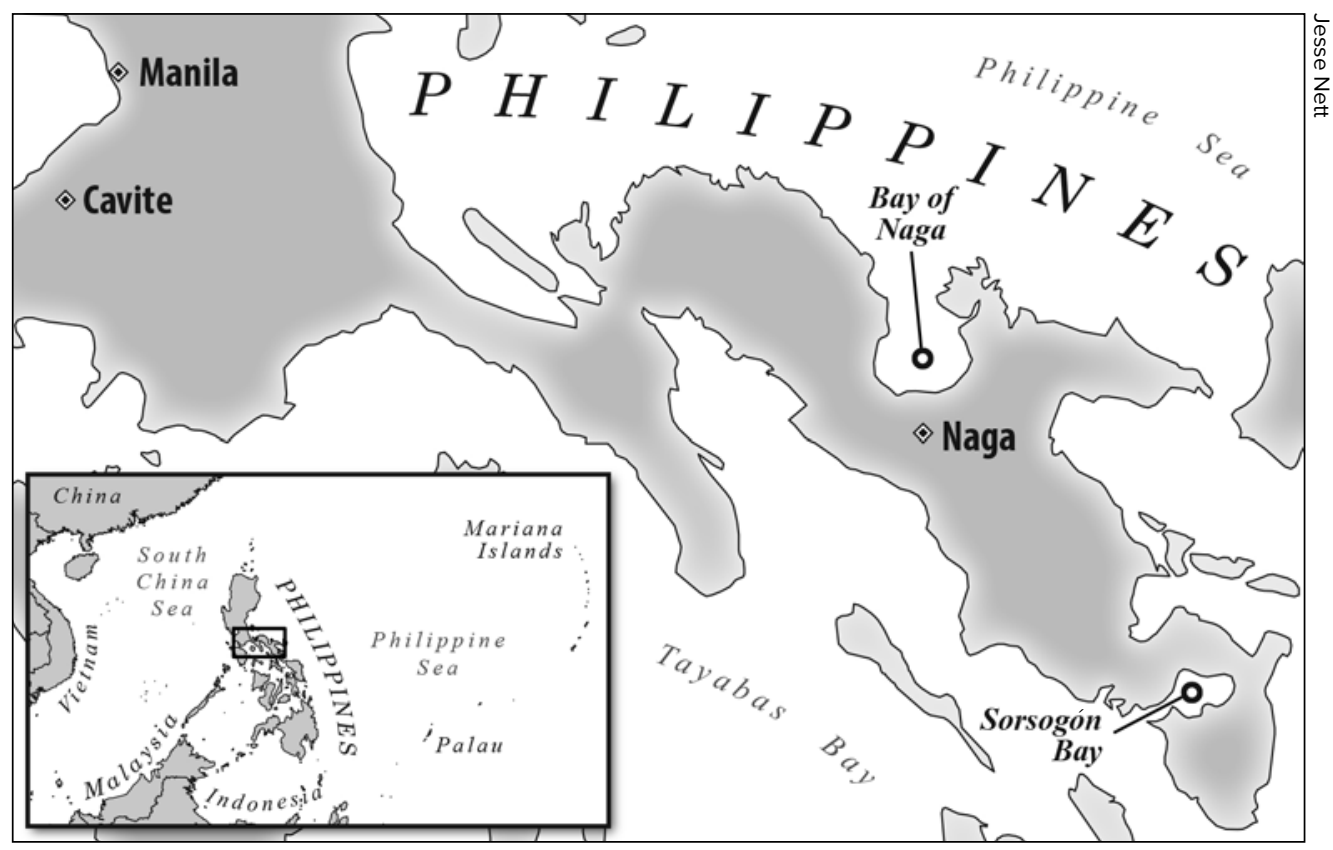

THE SANTO CRISTO DE BURGOS was built in Sorsogón (or Solsogón) Bay, which is pictured on the map of the Philippines above. In the forced return to port in 1692, the ship returned to the Bay of Naga (interchangeably referred to in contemporary documents as the Port of San Miguel de Quipaio), from which it sailed in the summer of 1692 for its final, fatal trip.

year-old, single man, born in the Canary Islands. He blamed the late sailing dates on contrary winds and suggested the arribada occurred because it was the time of year known for fierce storms. As might be expected, Quintero declared the masts were correct and instead blamed the boatswain for using rope for rigging that was not strong enough, and then for not tightening it sufficiently. To the accusation that he had a reputation for being a drunk and spending both days and nights sleeping, "he declared not having made certain observations at sea because either he did not consider them necessary, or because his assistant did so, or because he was ill. It is true that he drinks at times but never to the extreme of losing consciousness." 34

After much examination of witnesses, the officials' verdict exonerated del Bayo for the arribada but also warned him about the giving of orders to pilots concerning navigation routes. They judged Quintero guilty of choosing the wrong route and failing to take essential observations, stripped him of the right to work in his profession of galleon pilot, and permanently exiled him from the Philippines. ${ }^{35}$ 


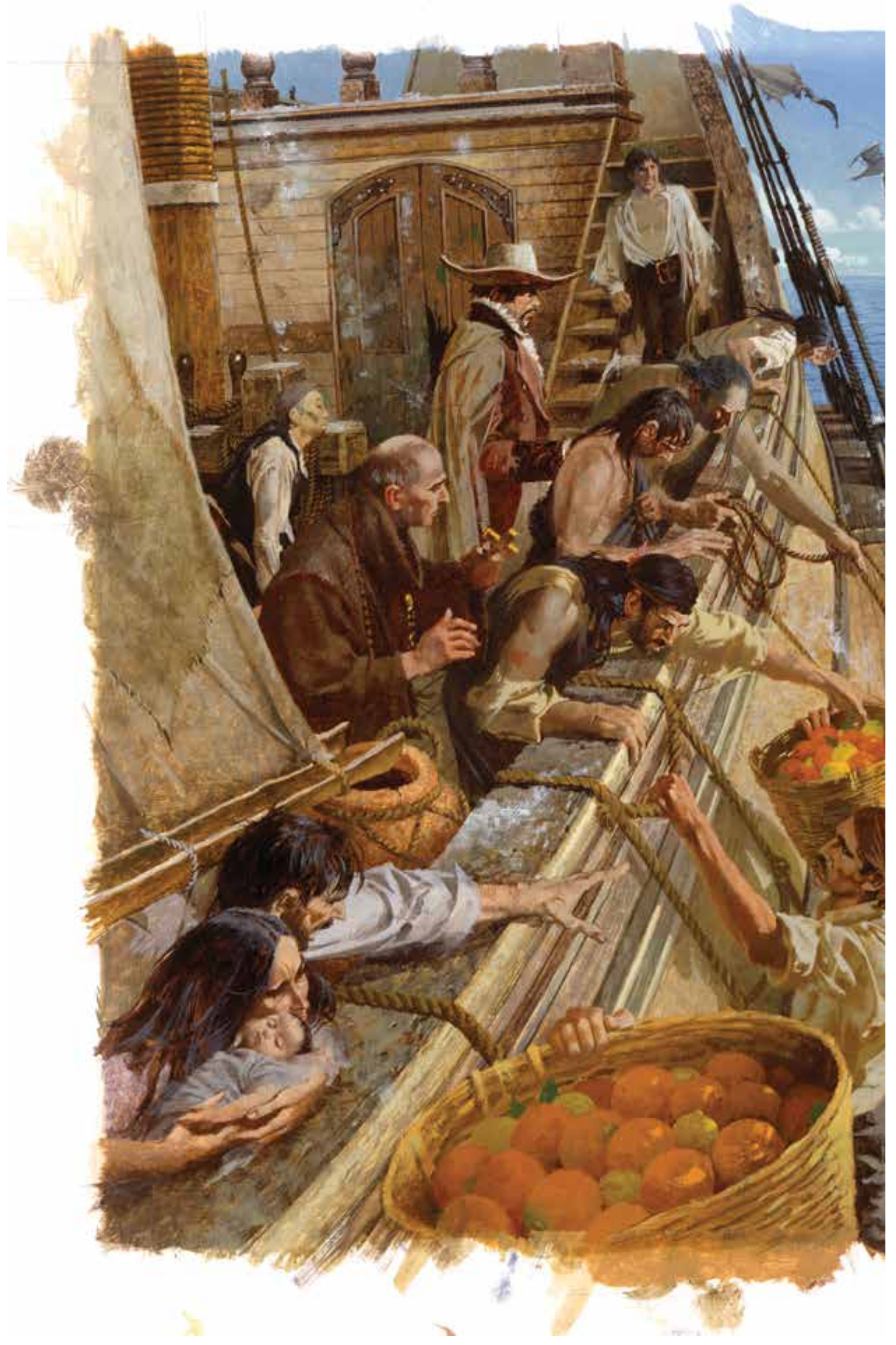




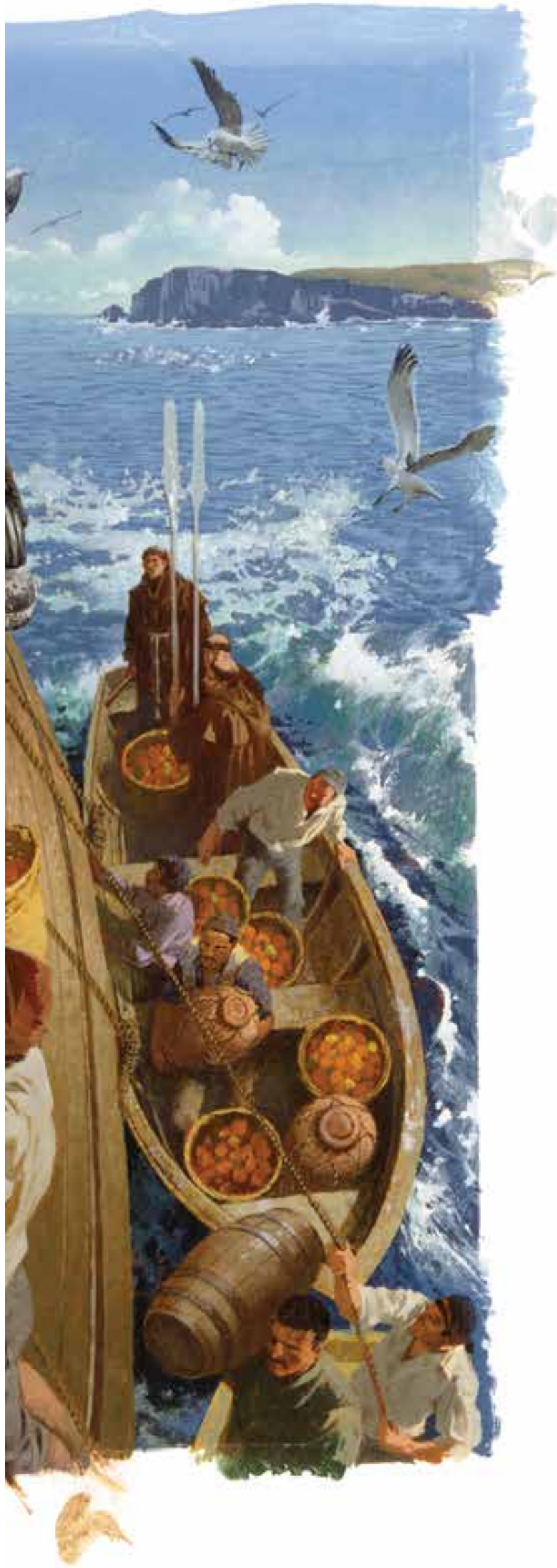

MANILA GALLEONS were cramped and crowded. When the voyage began, the galleon was filled with fresh fruit and vegetables, such as the oranges being purchased here. But as the voyage dragged across the North Pacific Ocean for six months or more, hunger and scurvy began to stalk the ship as food stores, especially fresh provisions, dwindled. This painting is by Robert McGinnis and is reproduced courtesy of National Geographic Creative. 
Not familiar with the job or the problems with the galleon's rigging, Pedro Flores, the thirty-four-year-old boatswain and native of Cadíz, Spain, caught much of the blame for the arribada. Originally the pilot's assistant, Flores had the ill luck to be appointed to the position after the original boatswain, Lorenzo Hernández, died. Officials held Flores responsible for not having been aware of bad rigging and for not adequately tightening the rigging, which led to the loss of the masts and sails. After appeal of an initial harsher sentence handed down in 1693, the Manila authorities rendered the final decision against Flores in November 1694. He was no longer permitted to work in his profession and was banished from Manila for ten years. If he failed to comply with the sentence, he would be sentenced to work in the galleys without salary. Flores had personal assets seized to pay damages of the arribada. ${ }^{36}$

At the request of some defendants, including Quintero, officials agreed to suspend further proceedings and take new testimonies and depositions once the galleon returned from Acapulco in 1693. ${ }^{37}$ Ultimately, in 1694, officials exonerated del Bayo of overloading the ship with cargo; but Flores and Quintero, both culpable in the disastrous arribada, had to pay the Royal Treasury for damages in addition to their other punishments. ${ }^{38}$

\section{THE SANTO CRISTO'S FATAL TRIP OF 1693}

The Santo Cristo underwent extensive repairs at the Naga shipyard through the winter and spring of 1693 , readying it for the summer trip to Acapulco. Documents detail payments to professional carpenters, caulkers, seamen, and overseers to buy necessary tools. Other records indicate that officials in 1693 authorized 13,175 pesos to pay eighty-five seamen, twenty-four Spanish gunners, sixty other gunners, and an unnumbered group of Indians working on the repairs. ${ }^{39}$ Maestro de campo Endaya traveled to the Naga shipyard to participate in, and likely oversee, the equipping and preparing of the Santo Cristo for its 1693 trip. $^{40}$

The ill will, drawn-out proceedings, and punitive verdicts resulting from the Santo Cristo's 1692 disaster directly affected the fatal 1693 trip. The process had been painful and time-consuming for the ship's commander and crew. Stung by the financial losses due to the arribada, which greatly damaged the Philippine economy, colonial officials both sought recompense from the ship's commander and senior crew and to hold them to high standards of financial accountability on future voyages. The governor placed del Bayo and other officials under obligation to repay the Treasury for repairs to the ship and to pay fianzas (securities) before being allowed to leave port. Del Bayo, in order to avoid paying this bond, departed port abruptly, leaving behind both men and critical supplies: "the said general D. Bernardo Iñiguez [del Bayo], as a way to avoid making this payment, 
precipitated his departure in all haste, so much so that he left on shore a large part of the supplies and more than 30 sailors who were necessary for the sailing of the galleon, men who will have been sorely missed for the trip and will have put the ship at risk." ${ }^{41}$ Reloaded with a full cargo, the ship left on July 1, 1693 - again departing port later than prudent for avoidance of storms in the San Bernardino Straits area.

Before the journey began, Manila officials gave del Bayo the galleon instructions. They provide an illuminating glimpse of life aboard the Santo Cristo de Burgos on what was supposed to be a routine, although hazardous, trading trip between Manila and Acapulco:

- The crew and passengers must confess their sins in all honesty. Mass and prayers will be celebrated every afternoon.

- The ship is to set sail in good condition, with sufficient seamen and artillery to defend itself against the enemy.

- Great care must be taken with the stoves, smoking is only permitted in this area where there are flames. Likewise, the only places permitted illumination are the binnacle, flags, and lanterns. When going below deck, lanterns are to be used and carried only by reliable persons.

- Food rations are to be observed with care; a third of the rations are to be saved should there be a delay in the journey. Necessary provisions are to be provided when coming into ports.

- Should it be necessary to lighten the ship during a storm, the articles on deck are to be offloaded before those below deck. Bundles are to be chosen rather than chests or pouches, and the cargo must be selected so that the losses are equally shared.

- If enemies are encountered, one must calculate how the ship must be defended so as to free itself from danger. The nighttime navigation route should be changed to then return to the official route of the journey. If this is not possible, the ship is to be defended until the very end.

- The ship is not to put into port unless absolutely necessary, and if so in the Philippines, not in Japan. This must be done observing the safety of the ship and the cargo aboard.

- The Generals of the ships have been appointed the responsibility of resolving any excesses or disturbances by the officials, seamen, or others travelling aboard the ship. The General is permitted to sentence or discipline these people. 
- No seaman or soldier who comes on board is permitted to disembark; this will be checked in Acapulco. Should there be any men sentenced to the galleys on board, these are to be watched and not permitted to have contact with one another so as to avoid any kind of conspiracy.

- It is not permitted to fire any artillery, either on arriving or setting sail from port, for military or religious salutes nor for any superfluous reasons. The artillery is only to be fired during an encounter with the enemy.

- During the journey, the infantry / soldiers aboard must check their arms and pass review each day. It is not permitted to play cards or any other type of game because this is prohibited on board.

- Should something happen to the General (Iñiguez del Bayo), a meeting of the officials is to be held and the orders and mandates for the General which are under lock and key are to be opened and read. A new General is to be appointed. The crown orders will be followed in relation to the appointing of Fleet and Armada Generals. The person named must observe these instructions for the rest of the journey.

- There is an explicit order that does not permit any silver or coins to be loaded on the ship which belong to any resident of Nueva España, whether it has been officially loaded on the ship or whether it is contraband. There will be fines against this cargo and the treasure withheld. A band [sic] is to be published and displayed on the ship for all to see. ${ }^{42}$

These orders governed daily life on the Santo Cristo during its voyage across the sea. But they would have become wildly irrelevant as the ship, under del Bayo's command, approached and wrecked in the homelands of the Nehalem-Tillamook people on today's Oregon coast. Additional research will answer the crucial question of whether that was the Santo Cristo's fate.

\section{OFFICERS AND CREW ABOARD THE SANTO CRISTO ON ITS FINAL VOYAGE}

Archival documents list the names of all crew from the Santo Cristo's 1693 trip, from the galleon general to the lowest seaman, along with the names of the sixteen passengers. The official crew and passenger list for 1693 was the same as for the unsuccessful 1692 voyage, which ended in the return 
to port. ${ }^{43}$ Although it is certain that some crew and passengers changed between the two trips, and some thirty crew members were left behind for the 1693 voyage, the archival lists provide no detail on those changes. Documents name the galleon's officers independently for the 1692 and 1693 voyages, however, due to the investigation of the arribada. We know, therefore, that the first pilot, assistant pilot, boatswain, chaplain, carpenter, and shipwright of the 1692 voyage did not sail on the 1693 voyage, being replaced by the men listed here. ${ }^{44}$ In addition, some of the crew, especially lightly clad and poorly fed Philippine seamen, likely died along the way, as deaths from scurvy, beriberi, and cold were common on the Manila galleon trade route - even without unexpected delays or detours through the cold northern Pacific. ${ }^{45}$ But if the Santo Cristo de Burgos is in fact the galleon that wrecked in the vicinity of Nehalem Spit, the majority of the men listed here probably died there, either in the wreck itself or in later skirmishes with Indigenous residents nearby. This wreck not only was a milestone historical event - the first known direct contact between Europeans, Asians, and Native peoples of that coast - but also was a tragedy of epic proportions. It therefore is appropriate to list all the men by name and profession. The ship's officers are listed in the table to the right.

\begin{tabular}{|c|c|}
\hline $\begin{array}{c}\text { SANTO CRISTO } \\
1693 \text { VOYAGE OFFICERS }\end{array}$ & PROFESSION \\
\hline $\begin{array}{c}\text { Don Bernardo Iñiguez del } \\
\text { Bayo }\end{array}$ & Galleon General \\
\hline Guillermo del Águlla & First Pilot \\
\hline Julián Rodriguez Godeño & Assistant Pilot \\
\hline Juan Andrés de Molina & Master \\
\hline Franciso Baptista Arquin & Boatswain \\
\hline Diego de Aro & Quartermaster's Mate \\
\hline Fray José Bea (Augustinian) & Chaplain \\
\hline Juan de Molina & Water Keeper \\
\hline Francisco de Silva Enríquez & Notary \\
\hline Vicente González & Diver \\
\hline Gerardo de Polduian & Steward \\
\hline Pascual de Asa & Carpenter \\
\hline Juan de Herrera y Pineda & Shipwright \\
\hline Bartolomé de Vallesilla & Surgeon \\
\hline Juan Francisco & Constable \\
\hline Gabriel de Moya & Captain \\
\hline Antonio de Bolaza & $\begin{array}{l}\text { Captain of Seamen } \\
\text { and Infantry }\end{array}$ \\
\hline Antonio García & Ensign \\
\hline
\end{tabular}

THIS TABLE COMPILES information on the Santo Cristo's 1693 voyage from the Ministerio de Educación, Cultura y Deporte, Archivo General de Indias, Filipinas 26, R.4, N.18, Doc.2, IM. 859-71 (in González Research Report to La Follette, January 2016, 21-22). 
Every one of these officers had a specific function in navigating the vessel and maintaining discipline. Among those mentioned in the documents, the commander, del Bayo, left behind the richest archival record. Don Bernardo Matias Iñiguez del Bayo y de Pradilla (to use his full name), the general of the Santo Cristo de Burgos, was a Basque nobleman from Tudela, in the Navarre region of the Basque country. He was baptized December 15, 1646, in Tudela's Collegiate Church (St. Mary's Cathedral of Tudela), and his birth would have been some days before. As the galleon's general, he was the chief officer. This was a highly sought-after position, and candidates often paid the governor 10,000 pesos to gain the coveted appointment. Salary ranged from 4,000 to 10,000 pesos, but galleon generals could add to their earnings by carrying cargo for Manila merchants while claiming it was their own freight. The merchants paid a commission for this service, and galleon generals and their officers greatly added to their earnings in this way. ${ }^{46}$ At the time of the ship's wreck, del Bayo was forty-seven or forty-eight years old.

Del Bayo had come to Mexico, presumably for the opportunities in the colonies of the Spanish Empire, in $1686 .{ }^{47}$ At the time of his appointment to galleon general, he was head of the mounted cuirassiers (cavalry) in Mexico City. From 1687 to August 1690, he was mayor of the mining town of San Luis de Potosí in the Mexican highlands, and Captain General on the Chichimeca borders. As alcalde (mayor), he oversaw town government, ensured the decrees of the King and Viceroy of New Spain were carried out - such as granting pardons to those who had come to New Spain without the proper license, and ensuring they paid their fines - and reported to the Viceroy as required about town administration. ${ }^{48}$

In addition to routine matters, del Bayo performed an invaluable service in San Luis de Potosí. The town was subject to severe and recurrent floods, which greatly damaged buildings and infrastructure. One of these occurred in August 1688, while del Bayo was mayor. He initiated and successfully completed construction of a large ditch (La Zanja) that ran around the city to carry the floodwaters away, ending flooding and flood damage for the first time in San Luis de Potosí, and for many decades thereafter. This piece of public-works construction cost 747 pesos; del Bayo donated 407 pesos of his own funds, and town residents contributed the remaining 340 pesos. ${ }^{49}$ The work was carried out under the oversight of senior sheriff Diego de Acevedo. The grateful town commissioned an altarpiece showing del Bayo and other officials worshiping Nuestra Señora del Pilar de Zaragoza, a patron of Spain. This painting still hangs in the parish church of Santiago in San Luis de Potosí..$^{50}$

Del Bayo was a knight of the Order of Santiago, an elite military Catholic order open only to those men able to prove four generations of nobility by 


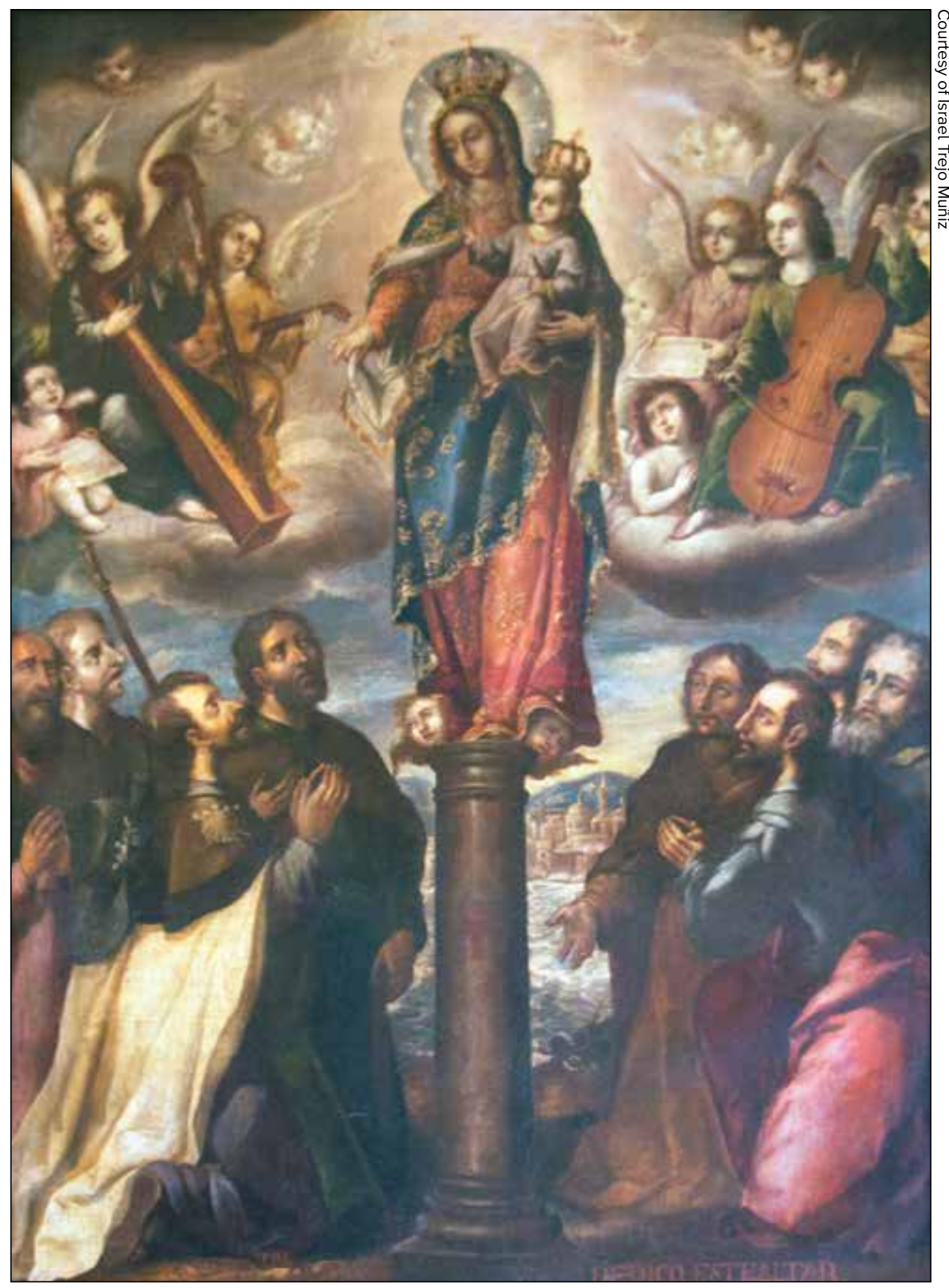

BASQUE GALLEON CAPTAIN Don Bernardo Iñiguez del Bayo served as mayor of the town of San Luis de Potosí from 1687 to 1690 . He oversaw the successful construction of the first ditch to carry floodwaters away from that town. In gratitude, the town commissioned this altarpiece painting, which is displayed in the parish church of Santiago. Del Bayo is the man in armor kneeling in the lower right foreground. 
blood and descent - not those who were granted nobility by monarchs. Applicants had to be of "Old Christian" heritage, without Moorish, Jewish, or converso (Jewish convert to Catholicism) blood, and sons of parents in legal matrimony. In order to become a Knight of Santiago, applicants had to provide many witnesses (also not of Jewish, converso, or Moorish blood), testifying to these and other matters; del Bayo provided thirty, as well as extracts from his father's and grandparents' wills. His father was Miguel Iñiguez del Bayo, advocate of the Royal Court in Navarre. Miguel acted as lieutenant mayor of Tudela and, at one time, was a candidate for mayor of Tudela - a position only open to the first rank of the nobility. Del Bayo's mother, Miguel's second wife, was María Pradilla, also from a noble family with roots in the kingdom of Aragón. The officials verified the family coat of arms: "Quarterly, 1st Azure a hollow cross of Calatrava, 2nd Or three red bands, 3rd Azure two kermes oaks, 4th Or a lion rampant." One witness, Pedro Magallar y Vergara, resident of Tudela and a Knight of Santiago, reported: "He has no knowledge and has heard nothing of the applicant or his forbears having practiced menial or manual labor, but rather knows the opposite to be true, having seen them live with splendor and good reputation, living off their rents and estates." Neither del Bayo nor his forbears had been penalized by the Inquisition or any other court; they were regarded as "good God-fearing Christians." 51

Second in command was the contramaestre primero (ship's master); on this trip, Juan Andrés de Molina held that position. He was responsible for the galleon's day-to-day operations, ensuring that all ran smoothly. The ship's masters were generally experienced navigators. If the galleon's commander died, the ship's master took command. The ship's master usually stayed with a galleon throughout its length of service, and Molina had been the ship's master in the Santo Cristo's 1692 voyage as well. ${ }^{52}$ The master was in charge of accounting for all the ship's cargo and was responsible for any losses of the merchandise. In Manila, the master also had the duty of overseeing the provisioning and outfitting of the galleon for the arduous voyage to Acapulco. He oversaw the crew members' tasks in the complex maintenance of the galleon voyage, which included everything from keeping the massive sails' rigging in shape to repairing leaks in the galleon hull under the waterline. ${ }^{53}$

Diego de Aro was the guardián (watchman, caretaker/quartermaster's mate), working as an assistant to the ship's master or the boatswain, probably with duties relating to daily shipboard administration and oversight, and to the watch. De Aro (or Haro) was a Basque from the province of Alava, although nothing more than his place of origin is known about him. ${ }^{54}$

The piloto mayor (chief pilot) was the third in command. Spanish regulations specified that Manila galleons had to carry three pilots. From the crew list, it appears that the Santo Cristo may have had only two pilots on 
the 1693 voyage - possibly due to the troubles in Manila, culminating in a hasty and furtive departure. The expertise of a third or even fourth pilot was no doubt sorely missed. The chief pilot on the voyage was Guillermo de Águlla. He was responsible for charting the galleon's course and ensuring that the ship reached its destination. Chief pilots were always experienced navigators with extensive experience at sea. They were also literate, as they had to make mathematical calculations, using the compass and astrolabe, and read sea maps. It was de Águlla's responsibility as chief pilot to ensure the night watches were kept rigorously on schedule, because sailing in the dark was always the most dangerous. ${ }^{55}$

The segundo contramaestre (boatswain) was the fourth-ranking crew member. This was Francisco Baptista Arquin on the fateful 1693 voyage, during which he gave most of the direct orders to the crew for running the ship and making necessary repairs. He was also largely responsible for the loading and unloading of cargo at port and for recording all the goods brought on board, and he had also served as the direct overseer of supplies and equipment loaded on the ship for the voyage. On the 1693 trip, with "critical supplies" left on land in the Philippines due to the early departure, Arquín's task must have been much more difficult, especially if repairs to wind-torn sails and damaged rigging were required, as they often were. ${ }^{56}$

On this voyage, the Santo Cristo's guardian primero (steward), the man in charge of the ship's cleanliness and safety, was Gerardo de Polduian. $\mathrm{He}$ had to ensure the decks were cleaned daily so the wood stayed moist and planks did not crack. Even more important, he oversaw all fires onboard especially cooking fires, which were always extinguished at the end of the day. Uncontrolled fire was the most terrifying prospect on a wooden vessel. We do not know who the despensero (food dispenser) was on this trip; he may have been one of those left behind. But someone would have taken over his duties, because his was a very important and powerful position on board the galleon: he meted out the crew's food and guarded the ship's provisions. Theft of food was a common problem on the galleons, especially when provisions were meager or rotten - often the case during voyages that could drag on six months or longer. The water-keeper (alquacil de agua) was similarly powerful and important, being in charge of dispensing water to passengers and crew. ${ }^{57}$ On this trip, the water-keeper was Juan Andrés de Molina.

Francisco de Silva Enríquez was the escrivano (notary) - the legal witness for all documents on board ship. He also recorded all cargo, equipment, and supplies on board as well as any damage to cargo. He had the delicate task of recording, and then, once in port, explaining how damage to cargo occurred, a task required to settle insurance claims. ${ }^{58}$

The Santo Cristo's cirujano (surgeon) was Bartolomé de Vallesilla. In the seventeenth century, the ship surgeon's job was often brutal, as he attended 
to the wounded and injured with primitive medicines and surgical instruments. He had to mix medicines from powders and make ointments; and if he had to amputate, he used saws and cauterizing implements. ${ }^{59}$ There was no anesthesia except alcohol or simply fainting away. The galleon also had a capellan (chaplain), an Augustinian priest named Fray José Bea, who officiated over religious services and prayers over the sick, the dying, and the dead. He no doubt shared this work with the six priests who were aboard as passengers on the Santo Cristo.

The Santo Cristo, like all galleons, also had a buso (diver), Vicente González. He had a difficult and demanding job: when damage to the ship's hull below waterline could not be repaired from inside the ship, he dove down and repaired it from the outside. The diver also removed barnacles, seaweed, and other sea wrack from the ship's rudder so it could steer. ${ }^{60}$

Manila galleons carried infantry and soldiers, in case of attack by enemies at sea. The captain of seamen and infantry on the Santo Cristo's 1693 voyage was Antonio de Bolaza. Such army commanders were usually unfamiliar with naval matters, but they were also in charge of ship discipline for crew members. Bolaza had under his direct command at least thirty-seven artilleros (gunners or artillerymen) aboard the final voyage of the Santo Cristo, so far as can be judged from the crew list that is listed in a table beginning on the facing page. ${ }^{61}$

The crew was as essential as the officers. Their tasks were many and varied, each necessary to keep the galleon running in good shape. Skilled repairmen were the lifeblood of the Manila galleon, sailing for six to nine months or even more across the trackless Pacific. On the final voyage of 1693 , we know there was a maestro carpintero (master carpenter), Pascual de Asa. $\mathrm{He}$ and his assistants were responsible for the care of all the wooden parts of the vessel, including the hull and the hundreds of wooden pulleys that moved the rigging system. If a mast was damaged in a storm, the carpenters' job was to repair it. ${ }^{62}$

The ship also should have had rope-makers, caulkers, and a sail-master. If the missing crew included these skilled men, their tasks had to be divided among the others. The Santo Cristo carried at least five blacksmiths (pandaye is the term used in the official records, blacksmith in Tagalog), plus a leader of blacksmiths. These men, skilled in working with iron, were essential craftsmen on board a galleon, repairing everything from nails to cannons. ${ }^{63}$

The gunners were in charge of the ship's cannons and guns when the ship was under attack. Many gunners began their working lives as sailors and learned the duties that allowed them to move into the position of experienced gunners. During the voyage, gunners participated in the night watches and nighttime adjustments of the rigging; they usually slept on the open main deck in order to be ready in case of attack. ${ }^{64}$ On Manila galleons, the 


\begin{tabular}{|c|c|}
\hline \multicolumn{2}{|c|}{ SANTO CRISTO } \\
1693 VOYAGE CREW & PROFESSION \\
\hline Andres de Camargo & Ayudante \\
\hline Bartolomé Gonzalez & Artilleryman \\
\hline Miguel de Izasti & Artilleryman \\
\hline Manuel de Ulloa & Artilleryman \\
\hline Antonia de Silva & Artilleryman \\
\hline Antonio Garcia & Artilleryman \\
\hline Manuel de Oliva & Artilleryman \\
\hline Juan de Fimbres & Artilleryman \\
\hline Juantilleryman
\end{tabular}

\begin{tabular}{|c|c|}
\hline $\begin{array}{c}\text { SANTO CRISTO } \\
1693 \text { VOYAGE CREW }\end{array}$ & PROFESSION \\
\hline Ignacio Vásquez & Artilleryman \\
\hline Pedro Pérez & Artilleryman \\
\hline Gabriel Izquierdo & Artilleryman \\
\hline Juan Rodríguez & Artilleryman \\
\hline Melchor Pérez & Artilleryman \\
\hline Juan de la Cruz & Artilleryman \\
\hline Juan Rodríguez de Lisboa & Artilleryman \\
\hline Tomás de Irún & Artilleryman \\
\hline Antonio Fernández & Artilleryman \\
\hline Juan de Morales & Artilleryman \\
\hline Marcos de Araguza & Artilleryman \\
\hline Juan de Cretio & Artilleryman \\
\hline Juan de Herrera Pineda & Artilleryman \\
\hline $\begin{array}{l}\text { Lucas Matías de Barra- } \\
\text { suada }\end{array}$ & Artilleryman \\
\hline José de Palacios & Artilleryman \\
\hline Pedro de Echavarría & Artilleryman \\
\hline Luis José & Artilleryman \\
\hline
\end{tabular}

THE TABLES on this page and the following pages compile information on the Santo Cristo's 1692 and 1693 voyages from the Ministerio de Educación, Cultura y Deporte, Archivo General de Indias, Filipinas 26, R.4, N.18, Doc.2, IM. 124-31 (in González Research Report to La Follette, March 2016, 14-18). 


\begin{tabular}{|c|c|}
\hline $\begin{array}{c}\text { SANTO CRISTO } \\
1693 \text { VOYAGE CREW }\end{array}$ & PROFESSION \\
\hline Gaspar de Ocampo & Artilleryman \\
\hline Antonio de Sicilia & Artilleryman \\
\hline Alfêrez José Ruiz & Artilleryman \\
\hline Andrés Suárez & Seaman \\
\hline Juan de Ulloa & Seaman \\
\hline Pedro Rodríguez & Seaman \\
\hline Andrés de la Cruz & Seaman \\
\hline Alberto el Flamenco & Seaman \\
\hline Pedro Esquerra & Seaman \\
\hline $\begin{array}{c}\text { Miguel de San José } \\
\text { Montes }\end{array}$ & Seaman \\
\hline Juan Calero & Seaman \\
\hline José García & Seaman \\
\hline Augustín Monabon & Seaman \\
\hline Francisco de Alarcón & Seaman \\
\hline Alonso Pérez & Seaman \\
\hline Juan Carillo de Cavite & Seaman \\
\hline Sebastián Pazco & Seaman \\
\hline Juan Bautista de Bacoor & Seaman \\
\hline
\end{tabular}

\begin{tabular}{|c|c|}
\hline $\begin{array}{c}\text { SANTO CRISTO } \\
1693 \text { VOYAGE CREW }\end{array}$ & PROFESSION \\
\hline Constantino de la Cruz & Seaman \\
\hline Juan Guillermo & Seaman \\
\hline Gaspar Jaramillo & Seaman \\
\hline Diego de Miranda & Seaman \\
\hline Jose de Viana & Seaman \\
\hline Fabián Faxardo & Seaman \\
\hline Juan Francisco Sotelo & Seaman \\
\hline Juan de Rivera & Seaman \\
\hline Gerónimo Andrés & Seaman \\
\hline Jose de Baraona & Seaman \\
\hline Francisco de Zotto & Seaman \\
\hline Manuel Rodríguez Prieto & Seaman \\
\hline Luis Rodríguez & Seaman \\
\hline Juan Jaçin & Seaman \\
\hline Francisco Díaz & Seaman \\
\hline Antonio Sarmiento & Seaman \\
\hline Sebastián Ximenes & Seaman \\
\hline Nicolás Manito & Seaman \\
\hline
\end{tabular}




\begin{tabular}{|c|c|}
\hline $\begin{array}{c}\text { SANTO CRISTO } \\
1693 \text { VOYAGE CREW }\end{array}$ & PROFESSION \\
\hline Juan Jorge de Melo & Seaman \\
\hline Augustin de Rivera & Seaman \\
\hline $\begin{array}{c}\text { Bartolomé González de } \\
\text { Parañaque }\end{array}$ & Seaman \\
\hline Juan de los Santos & Seaman \\
\hline Matías de los Reyes & Seaman \\
\hline Pedro Díaz & Seaman \\
\hline $\begin{array}{c}\text { Agustín Pérez de San } \\
\text { Roque }\end{array}$ & Seaman \\
\hline Ambrosio Hernández & Seaman \\
\hline Nicolás de la Cruz del Bay & Seaman \\
\hline Francisco Beltrán & Seaman \\
\hline Nicolás Martín & Seaman \\
\hline Pedro de Alcántara & Seaman \\
\hline Francisco de Acevedo & Seaman \\
\hline Juan Carillo de la Puebla & Seaman \\
\hline $\begin{array}{l}\text { Pedro de la Cruz de San } \\
\text { Roque }\end{array}$ & Seaman \\
\hline Pablo Guerra & Seaman \\
\hline Antonio de Cosío & Seaman \\
\hline $\begin{array}{l}\text { Andrés de la Cruz de San } \\
\text { Palo }\end{array}$ & Seaman \\
\hline
\end{tabular}

\begin{tabular}{|c|c|}
\hline $\begin{array}{c}\text { SANTO CRISTO } \\
1693 \text { VOYAGE CREW }\end{array}$ & PROFESSION \\
\hline Francisco Villagudin & Seaman \\
\hline Luis de la Cruz de Manila & Seaman \\
\hline $\begin{array}{c}\text { Agustín de la Cruz de } \\
\text { Cavite }\end{array}$ & Seaman \\
\hline Andrés de Xara & Seaman \\
\hline Juan Rodriguez Chano & Seaman \\
\hline José Montejo & Seaman \\
\hline Luis Lozano & Seaman \\
\hline Diego Muñoz & Seaman \\
\hline Pedro Telmo & Seaman \\
\hline Francisco del Valle & Seaman \\
\hline Juan Valdés & Seaman \\
\hline Manuel Navarro & Seaman \\
\hline Juan Navarro & Seaman \\
\hline Miguel Rodríguez & Seaman \\
\hline Marcos Rodríguez & Seaman \\
\hline Manuel Pérez & Seaman \\
\hline Juan Fernández & Seaman \\
\hline $\begin{array}{c}\text { Esteban de Torres el } \\
\text { Grande }\end{array}$ & Seaman \\
\hline
\end{tabular}




\begin{tabular}{|c|c|}
\hline $\begin{array}{c}\text { SANTO CRISTO } \\
1693 \text { VOYAGE CREW }\end{array}$ & PROFESSION \\
\hline $\begin{array}{l}\text { Agustín de la Cruz el } \\
\text { Mozo }\end{array}$ & Seaman \\
\hline José Francisco & Seaman \\
\hline Juan Pascual & Seaman \\
\hline Domingo de Hirón & Seaman \\
\hline Domingo de Molina & Seaman \\
\hline Gregorio de Barros & Seaman \\
\hline Augustín de los Reyes & Seaman \\
\hline Miguel de Origuey & Seaman \\
\hline Diego de Rosas & Seaman \\
\hline Juan Xinete & Seaman \\
\hline Ventura Santos & $\begin{array}{l}\text { Seaman (leader } \\
\text { of the pandayes } \\
\text { [blacksmiths] }\end{array}$ \\
\hline Juan Martín & Seaman \\
\hline Juan de Guevara & Seaman \\
\hline Juan Pastraña & $\begin{array}{c}\text { Spanish Grummet } \\
\text { [apprentice } \\
\text { seaman] }\end{array}$ \\
\hline $\begin{array}{l}\text { Manuel de la Cruz de } \\
\text { Manila }\end{array}$ & Spanish Grummet \\
\hline Francisco González & Spanish Grummet \\
\hline Nicolás Ruiz de Colina & Spanish Grummet \\
\hline
\end{tabular}

\begin{tabular}{|c|c|}
\hline $\begin{array}{c}\text { SANTO CRISTO } \\
1693 \text { VOYAGE CREW }\end{array}$ & PROFESSION \\
\hline Lorenzo de la Cruz & Spanish Grummet \\
\hline José Gallegos & Spanish Grummet \\
\hline Jacinto Ronquillo & Spanish Grummet \\
\hline $\begin{array}{c}\text { Juan Bautista de Buena } \\
\text { Ventura }\end{array}$ & Spanish Grummet \\
\hline Tomás López de Oria & Spanish Grummet \\
\hline Miguel Nieto & Spanish Grummet \\
\hline Juan del Río & Spanish Grummet \\
\hline Diego de la Cruz & Spanish Grummet \\
\hline Ambrosio de la Cruz & Spanish Grummet \\
\hline José de la Cruz & Spanish Grummet \\
\hline Francisco Rodríguez & Spanish Grummet \\
\hline Juan Flores & Spanish Grummet \\
\hline Francisco Juan & $\begin{array}{c}\text { Spanish Grummet, } \\
\text { Panday }\end{array}$ \\
\hline Augustín Candao & Spanish Grummet, \\
\hline Juan Muñoz & $\begin{array}{c}\text { Spanish Grummet, } \\
\text { Panday }\end{array}$ \\
\hline Vicente de la Cruz & $\begin{array}{c}\text { Spanish Grummet, } \\
\text { Panday }\end{array}$ \\
\hline Nicolás Marcelo & $\begin{array}{l}\text { Spanish Grummet, } \\
\text { Barrendador [borer] }\end{array}$ \\
\hline Lorenzo Pérez & $\begin{array}{c}\text { Spanish Grummet, } \\
\text { Barrendador }\end{array}$ \\
\hline
\end{tabular}




\begin{tabular}{|c|c|}
\hline $\begin{array}{c}\text { SANTO CRISTO } \\
1693 \text { VOYAGE CREW }\end{array}$ & PROFESSION \\
\hline Juan Flores & $\begin{array}{c}\text { Spanish Grummet, } \\
\text { Barrendador }\end{array}$ \\
\hline Miguel de Aguilera & $\begin{array}{l}\text { Grumet Sencillo } \\
\text { [apprentice } \\
\text { seaman] }\end{array}$ \\
\hline Benito García & Grumet Sencillo \\
\hline Pedro de la Cruz & Grumet Sencillo \\
\hline Juan de Mendoza & Grumet Sencillo \\
\hline Domingo de la Cruz & Grumet Sencillo \\
\hline José de Zamora & Grumet Sencillo \\
\hline Manuel de Piedra Santa & Grumet Sencillo \\
\hline Francisco de Torres & Grumet Sencillo \\
\hline Juan Felipe & Grumet Sencillo \\
\hline Pedro Martín & Grumet Sencillo \\
\hline Juan Navarro Rodríguez & Grumet Sencillo \\
\hline Pedo García & Grumet Sencillo \\
\hline Francisco de Aguilar & Grumet Sencillo \\
\hline Juan Mandinga de Yloylo & Grumet Sencillo \\
\hline Juan Livanag & Grumet Sencillo \\
\hline Melchior de Gorrustola & Grumet Sencillo \\
\hline
\end{tabular}

\begin{tabular}{|c|c|}
\hline $\begin{array}{c}\text { SANTO CRISTO } \\
1693 \text { VOYAGE CREW }\end{array}$ & PROFESSION \\
\hline Pedro de Brassa & Grumet Sencillo \\
\hline $\begin{array}{c}\text { Jose Romero, from Nueva } \\
\text { España }\end{array}$ & Grumet Sencillo \\
\hline $\begin{array}{l}\text { Juan de Medina, from } \\
\text { Cavite }\end{array}$ & Grumet Sencillo \\
\hline Pedro Manuel de Cavite & Grumet Sencillo \\
\hline $\begin{array}{c}\text { Lorenzo de Aldana, from } \\
\text { Ylocos }\end{array}$ & Grumet Sencillo \\
\hline $\begin{array}{c}\text { Gabriel de la Cruz from } \\
\text { Pangasinán }\end{array}$ & Grumet Sencillo \\
\hline $\begin{array}{c}\text { Augustín de la Cruz, from } \\
\text { Ylocos }\end{array}$ & Grumet Sencillo \\
\hline $\begin{array}{c}\text { Pedro Díaz, from Pangas- } \\
\text { inán }\end{array}$ & Grumet Sencillo \\
\hline $\begin{array}{c}\text { Augustín Hernandez, from } \\
\text { Pangasinán }\end{array}$ & Grumet Sencillo \\
\hline $\begin{array}{c}\text { Miguel de la Rosa, from } \\
\text { Pampagna }\end{array}$ & Grumet Sencillo \\
\hline $\begin{array}{l}\text { Andrés de Peralta, from } \\
\text { Cavite }\end{array}$ & Grumet Sencillo \\
\hline $\begin{array}{c}\text { Jacinto de Aro, from } \\
\text { Pangasinan }\end{array}$ & Grumet Sencillo \\
\hline $\begin{array}{l}\text { Miguel de Aro, from } \\
\text { Pampanga }\end{array}$ & Grumet Sencillo \\
\hline Diego de Medina & Grumet Sencillo \\
\hline Diego Estévez & Grumet Sencillo \\
\hline $\begin{array}{c}\text { Alonso Caravallo, from } \\
\text { Cavite }\end{array}$ & Grumet Sencillo \\
\hline $\begin{array}{c}\text { Juan Esquerra, from } \\
\text { Cavite }\end{array}$ & Grumet Sencillo \\
\hline
\end{tabular}




\begin{tabular}{|c|c|}
\hline $\begin{array}{c}\text { SANTO CRISTO } \\
1693 \text { VOYAGE CREW }\end{array}$ & PROFESSION \\
\hline $\begin{array}{l}\text { Francisco de Mendoza, } \\
\text { from Cavite }\end{array}$ & Grumet Sencillo \\
\hline $\begin{array}{l}\text { Augustín Manabat, from } \\
\text { Manila }\end{array}$ & Grumet Sencillo \\
\hline $\begin{array}{c}\text { Andrés de Guevara, from } \\
\text { Cavite }\end{array}$ & Grumet Sencillo \\
\hline Pablo de la Cruz & Grumet Sencillo \\
\hline $\begin{array}{c}\text { Pedro Macaray Lay, from } \\
\text { Cavite }\end{array}$ & Grumet Sencillo \\
\hline $\begin{array}{c}\text { Fernando Quevedo, from } \\
\text { España }\end{array}$ & Grumet Sencillo \\
\hline $\begin{array}{c}\text { Juan Baptista, from Las } \\
\text { Piñas }\end{array}$ & Grumet Sencillo \\
\hline $\begin{array}{l}\text { Francisco Rendón, from } \\
\text { San Roque }\end{array}$ & Grumet Sencillo \\
\hline $\begin{array}{l}\text { Francisco Martínez, from } \\
\text { Panay }\end{array}$ & Grumet Sencillo \\
\hline $\begin{array}{c}\text { Roque de Alvarado, from } \\
\text { San Roque }\end{array}$ & Grumet Sencillo \\
\hline $\begin{array}{c}\text { Diego Magnay, from } \\
\text { Cavite }\end{array}$ & Grumet Sencillo \\
\hline $\begin{array}{l}\text { Juan de León, from Las } \\
\text { Piñas }\end{array}$ & Grumet Sencillo \\
\hline $\begin{array}{l}\text { Antonio de los Santos, } \\
\text { from Nueva España }\end{array}$ & Grumet Sencillo \\
\hline
\end{tabular}

\begin{tabular}{|c|c|}
\hline $\begin{array}{c}\text { SANTO CRISTO } \\
1693 \text { VOYAGE CREW }\end{array}$ & PROFESSION \\
\hline $\begin{array}{c}\text { Tomás de la Cruz, from } \\
\text { Las Piñas }\end{array}$ & Grumet Sencillo \\
\hline $\begin{array}{l}\text { José de León, from Las } \\
\text { Piñas }\end{array}$ & Grumet Sencillo \\
\hline $\begin{array}{c}\text { Francisco de la Cruz, from } \\
\text { Cavite }\end{array}$ & Grumet Sencillo \\
\hline $\begin{array}{c}\text { Nicolás de la Cruz, from } \\
\text { Las Piñas }\end{array}$ & Grumet Sencillo \\
\hline $\begin{array}{l}\text { Pedro de Rivera, from Las } \\
\text { Piñas }\end{array}$ & Grumet Sencillo \\
\hline Tomás Sangalan & Grumet Sencillo \\
\hline $\begin{array}{c}\text { Ignacio Francisco, from } \\
\text { Dilao }\end{array}$ & Grumet Sencillo \\
\hline $\begin{array}{l}\text { Diego de Ordaña, from } \\
\text { España }\end{array}$ & Grumet Sencillo \\
\hline $\begin{array}{c}\text { Antonio de la Cruz, from } \\
\text { España }\end{array}$ & Grumet Sencillo \\
\hline $\begin{array}{c}\text { Tomás Marcos, from Para- } \\
\text { ñaque }\end{array}$ & Grumet Sencillo \\
\hline Nicolás de Mendiola & Grumet Sencillo \\
\hline Manuel de Castro & Grumet Sencillo \\
\hline
\end{tabular}

gunners were typically Mexican or Spanish, as seems the case of the Santo Cristo de Burgos, if the names of the men reflect their likely place of origin.

A Manila galleon customarily carried about 130 sailors. Officers and skilled crew were usually Spanish or perhaps Mexican. There was frequently a high percentage of Basques among the officers and crew as well as among the merchants who were shipping trade goods on the galleons; the Basque people, living on the Bay of Biscay, had a long seafaring and shipbuilding 
tradition that was crucial to the success of the Spanish maritime empire. ${ }^{65}$ Other crew - especially seamen and apprentices - were largely Filipino, with some Mexicans as well. A common ratio of Filipinos to Spaniards on a Manila galleon was five-to-one. ${ }^{66}$ Aboard the Santo Cristo, it is clear from the crew list that there was a group of Spanish apprentices, specifically labeled as such. But many crew, including a good-size group of apprentices, were Filipino. Despite the Spanish names, men who listed their place of origin to Philippine locations (such as Parañaque, Cavite, Las Piñas, Manila, or Pampanga) are very likely to have been Filipino. Other crew who did not list a place of origin may well have been Mexican.

Many Filipinos were press-ganged to work aboard the galleons, as allowed by Spanish law of the time. If originating from the coastal areas of the Philippines, Native Filipino men often had nautical skills before entering the galleon trade and had a better chance of surviving the harsh life on board trans-Pacific voyages. Nevertheless, it was common for Spanish officers to treat the Filipino sailors poorly, give them less food (often half rations, especially as the voyage ground on for months and provisions dwindled), less warm clothing for the northern latitudes, and a salary only half the amount paid to Spaniards. The pressganged Filipinos were frequently of farming families and knew little to nothing of seafaring before being forced into service; this, combined with harsh treatment and tempestuous weather, meant that many died en route. ${ }^{67}$

The crew list included grumetes (apprentices), who were usually young sailors training to become experienced crew. Their jobs took advantage of their agility; they frequently served as oarsmen, lookouts, and personal servants to the officers - who in turn protected the apprentices from the rough behavior of some seamen. The pages were the youngest crew members and had all the menial jobs aboard ship: they turned the sand clocks to keep track of the time, washed down the decks twice a day, and recited aloud from books of psalms or prayers both for the benefit of the crew and to help keep the ship from danger. In Spain, galleon captains frequently rounded up boys who were orphans, runaways, or abandoned children between ages twelve and sixteen, often roaming the streets of port towns, to serve in these positions. In the Philippines, some pages may have been street children of Manila, but it is more likely that they were forced into their positions, removed from their homes by Spanish authority. ${ }^{68}$

\section{PASSENGERS ABOARD THE SANTO CRISTO OF 1693}

The Santo Cristo carried about sixteen passengers in 1693, including six priests, although not all who were listed in the records did in fact travel on the galleon in 1693. The listed passengers are reproduced in the table on the following page. The records yielded a slight amount of information about a 
few of these passengers - just enough for us to see that they were known in their communities.

In the case of Augustinian Fray (friar) Francisco de Ugarte, the record is complex and perhaps contradictory. Priests and missionaries were quite mobile in the Spanish empire, and it is certainly possible that Fray Ugarte traveled between Spain, Peru, and the Philippines as the three different records of his life suggest. Most records concur that he was a native of the Basque region of northern Spain. The most detailed document states that he was born in the Apricano Valley of Cuartango, in the province of Álava. He was the son of Francisco de Ugarte and María López de Robles. In 1690, he was given permission to travel to Peru, presumably as a missionary. ${ }^{69}$ According to a fellow Augustinian priest, Ugarte was from Vizcaya, in the Basque region near the Bay of Biscay - just north of Álava. Casimiro Diaz, an Augustinian priest residing in the Philippines, wrote of him in 1694: "Among the persons who were lost in this galleon [Santo Cristo de Burgos] was a religious who was most highly esteemed by this province for his great virtue and learning; this was the father reader Fray Francisco de Ugarte [sic], a Vizcayan, native of Marquina, who came as superior of the mission which reached this province in the year 1684; he had been sent in this galleon to España, as procurator of the province, to ask for a new reinforcement of missionaries. Much could be said of the great virtue this religious, of his frequent prayer and mortification, his poverty, his extraordinary humility and affability."70

Possibly aboard the Santo Cristo was Fray Juan de Paz, a Dominican born in the Philippines about 1623, according to one source; according to another, he came to the Philippines in $1648 .{ }^{71}$ Known as a famous Dominican moralist in the Philippines, he was called the "Universal Oracle of Asia," due to his reputation for concise and sound moral judgments. His opinions were often requested on difficult moral questions or situations - "cases of conscience," as they were called - not covered by either the Church's Canon Law or the Spanish laws governing the Indies. Such questions included, for example, kinds of slavery and price of slaves in the Philippines; problems stemming from individuals of uncertain civil status; treatment of Chinese residents in Manila; lapses from duty, such as extortion, of local alcaldes (mayors) and other provincial officials; abuse of Filipino farmers in the collection of tribute, by both Native Filipino and Spanish soldiers and officials; and the continuing problems that arose as priests, especially in rural areas of the Philippines, tried to find adequate ways of supporting themselves..$^{72}$

De Paz studied arts and theology at the University of Santo Tomás in Manila, and then taught there, becoming successively regent, rector, and chancellor. One document describes him as follows: "Fray Juan de Paz is very zealous with regard to the spiritual care of souls. He is a preacher and 
reader of Arts and Theology from the University of Santo Tomás. He was born in the Philippines, he is over forty years old, and is of noble birth. He has been a minister in the province of Nueva Segovia, and a regent in the University of Santo Tomás. He is a learned man, virtuous and an example to follow, he is most affable and admired by all."73 Despite this, de Paz raised some hackles in the Philippines with his outspoken judgments. In 1685, for example, Fray Bartolome Marron, at that time Rector of the College of Santo Tomás, refused to grant de Paz the license to publish one of his books in Manila, so de Paz arranged for it to be printed in Seville. Marron described his reasons in a letter to the General of the Dominican Order: "That in the book there are many opinions touching on matters of faith and others which tarnish the honor of some persons, who will be very easy to identify in these islands when the printed book arrives here." ${ }^{74} \mathrm{De} \mathrm{Paz}$, however, had powerful protection in high places. Marron complained in exasperation that de Paz "lives in a separate house and has breached many of the precepts of his prelates; not only can he not be punished, it is not even possible to speak to him, as he has the support of the Bishop and other figures." 75 He had also given testimony against a corrupt governor of the Philippines, Belgian-born Diego de Salcedo, a former Spanish Army officer (ruled

\begin{tabular}{|c|c|}
\hline $\begin{array}{l}\text { SANTO CRISTO } 1693 \\
\text { VOYAGE PASSENGERS }\end{array}$ & PROFESSION \\
\hline Fray Juan de Paz & $\begin{array}{l}\text { Priest, Dominican } \\
\text { Order }\end{array}$ \\
\hline Fray Diego Burguillos & $\begin{array}{l}\text { Priest, Dominican } \\
\text { Order }\end{array}$ \\
\hline Fray José de Valdés & $\begin{array}{c}\text { Priest, Dominican } \\
\text { Order } \\
\end{array}$ \\
\hline Fray Francisco de Ugarte & $\begin{array}{c}\text { Priest, Augustinian } \\
\text { Order }\end{array}$ \\
\hline Fray Pedro de Casanova & Priest, Jesuit Order \\
\hline Fray Mauricio Perera & Priest, Jesuit Order \\
\hline $\begin{array}{c}\text { Seargeant Major Pedro de } \\
\text { Lequeder y Garabalda }\end{array}$ & none listed \\
\hline $\begin{array}{c}\text { Seargeant Major Pedro de } \\
\text { Olasaval }\end{array}$ & none listed \\
\hline Captain Luis de Espinosa & none listed \\
\hline Captain Juan de Aguirre & none listed \\
\hline $\begin{array}{c}\text { Captain Juan Moreno de } \\
\text { Viniegra }\end{array}$ & none listed \\
\hline $\begin{array}{c}\text { Captain Pedro de Eche- } \\
\text { varría }\end{array}$ & none listed \\
\hline $\begin{array}{c}\text { Captain Antonio de } \\
\text { Palacios }\end{array}$ & none listed \\
\hline $\begin{array}{c}\text { Adjutant José Gonzaléz } \\
\text { Rexón }\end{array}$ & none listed \\
\hline Juan Hernández Gutiérrez & none listed \\
\hline $\begin{array}{c}\text { Captain Francisco de } \\
\text { Inestrossa }\end{array}$ & none listed \\
\hline
\end{tabular}

THIS TABLE COMPILES information on the Santo Cristo's 1692 and 1693 voyages from Ministerio de Educación, Cultura y Deporte, Archivo General de Indias, Filipinas 26, R.4, N.18, Doc.2, IM. 859-871 (in González Research Report to La Follette, January 2016, 21-22). 
1663-1668), to have him arrested by the Inquisition for crimes against the Church. The archbishop of Manila had put de Paz's name forward for bishop of the Philippine Islands. ${ }^{76}$

It must be noted that, although the AGI passenger record for the Santo Cristo de Burgos of 1692-1693 lists de Paz as a passenger, one secondary source states that he died in $1698 .{ }^{77}$ This of course would mean he was not on the Santo Cristo's fatal 1693 trip, although he may well have been on board the abortive 1692 trip. The authors were unable to locate a primary documentary source for de Paz's death.

Passenger Fray José de Valdés, a Dominican priest, was born in Avilés, a town in the region of Asturias in north-central Spain. ${ }^{78}$ Fray Pedro de Casanova, Jesuit priest, was born in Velez Blanco, in the Almeria province of southern Spain, in the Andalusia region. ${ }^{79}$

Passenger Captain Francisco de Inestrossa was in trouble with the Spanish administration in the Philippines for smuggling. ${ }^{80}$ So, too, was Sergeant Major Pedro Lequeder y Garabalda, a citizen of Mexico City residing in the Philippines prior to the 1693 voyage. ${ }^{81}$ Years after the Santo Cristo's loss, Lequeder's nephew, Juan de Huarte y Lequeder, secretary to His Majesty and Royal Treasurer General, petitioned for a death certificate. He requested that the Secretary of New Spain, Francisco de Vera y Valencia, certify the loss of the galleon with all crew and passengers, including his uncle. The secretary duly certified the loss. ${ }^{82}$

Captain Juan Moreno de Viniegra was born in Anguiano, a small town located in the north-central La Rioja province of Spain. He was aboard the galleon with a license to travel to Mexico. ${ }^{83}$ Captain Antonio de Palacios is mentioned as a captain of the artillery in Terrenate, a city and surrounding municipality in the Mexican state of Tlaxcala. ${ }^{84}$

A few fortunate souls probably escaped the fate of the 1693 shipwreck in addition to the thirty or so crew left behind - but we only know of one for certain, by his name. Captain Luis de Espinosa is mentioned in a document as a businessman of Seville - "an exporter to the Indies [who] has made several voyages with shipments of goods, together with other merchants." $85 \mathrm{He}$ apparently sailed on the Santo Cristo's abortive 1692 voyage, because he is listed as a passenger; but he was not traveling on the fatal 1693 galleon trip, because documents show him granting power of attorney in $1712 .{ }^{86}$

It is possible that slaves were aboard the ship during its final voyage, because the galleons frequently carried enslaved people, despite Spanish restrictions on the slave trade. A 1608 law prohibited galleon officers from carrying slave women as concubines on the voyage and directed that any be seized once the ship reached Acapulco. A 1626 law levied a 500-peso tax on every slave brought from the Philippines, and a royal order of 1700 prohibited slave trading altogether. Nevertheless, slaves, even from South Africa, were 
sometimes sold in Acapulco; and galleon passengers frequently disposed of their personal servants at the end of the voyage by selling them, as apparently Giovanni Gemelli Careri, the 1697 galleon passenger, did with an enslaved African in his possession. ${ }^{87}$ Slavery in the Philippines was still practiced during the late seventeenth century, although the Spanish were technically not allowed to own slaves. Poverty often forced Philippine parents to sell their children into servitude; other slaves were war captives or those condemned to slavery by judicial order. Slavery did not always last for a lifetime: the master possessed title to a slave's work, but not always the whole person. Still, enslaved people were often sold as property. ${ }^{88}$ The records of the Santo Cristo de Burgos do not mention slaves of any nationality. The listing of slaves, with the legal status of possessions rather than of citizens or even laborers, was not a common practice.

\section{THE SHIPWRECK, THE ARCHIVAL FINDINGS, AND OREGON HISTORY}

Now, based on the archival evidence, we know why the Santo Cristo was more vulnerable to shipwreck than might otherwise have been the case. The ship assumed unusual risk by leaving the Philippines hastily to avoid financial penalties for the events of 1692, without key supplies and crew. Even modest damage at sea due to storms or other events may have proved fatal to the Santo Cristo under these circumstances. Based on historical records and galleon technology, a fierce storm is the most likely culprit for the wreck, perhaps magnified by the ship's vulnerabilities. The results of this archival research will no doubt have broader implications that will become clear as archaeological research on the galleon continues. The specifics of ship construction apparent in the archival record - down to the names and personal histories of shipwrights, specific forests that were sources of the wood, and minutiae such as the use of recycled iron nails - all provide tantalizing clues and guideposts for future archaeological searches and testing.

The details of the Santo Cristo de Burgos and its crew and passengers, published here for the first time, bring the larger story of the galleon to light - removing the tale from the misty domain of speculation and placing the details of the men whose lives ended, probably on today's north Oregon coast, firmly within the context of Spanish colonial history. The richly detailed records recovered from the colonial archives of Spain, Mexico, and the Philippines provide us with revealing glimpses of perhaps the first Europeans, and maybe the first Asians and Central Americans, to encounter coastal Oregon. They were brought together by the astonishing diversity of the trans-Pacific galleon trade, traveling as soldiers, administrators, priests and missionaries, mariners and merchants throughout South and Central America and the Span- 
ish colony in the Philippines. The Manila trade made this possible, drawing peoples together that hitherto had had no contact with one another - sometimes accidentally, as a result of shipwrecks and other unanticipated landfalls throughout the Pacific region. That included the coast of Oregon, some 112 years before Meriwether Lewis and William Clark looked out over the Pacific Ocean and first obtained "bears wax" from tribal traders, just a day's walk north of the galleon wreck site. ${ }^{89}$

Their point of landfall aside, the scale of the loss, when seen in these human terms, was immense. With so many men lost in a single voyage, distant port communities were left in turmoil, with families mourning, impoverished, and facing uncertain futures. The economic effects of the lost cargo were also disastrous for the colonies. If the Santo Cristo's 1692 arribada and the complete loss of the ship in 1693 were not sufficiently painful, the 1694 galleon, the San José, foundered in the Marianas with total loss of the crew and passengers, and the rich cargo. More than four hundred people drowned. ${ }^{\circ 0}$ Domingo de Valencia, Dean of Manila Cathedral, testified to the burdens on the Philippine colony: "it [the Santo Cristo de Burgos] set sail for New Spain the next year, 93, and many badly damaged packages were taken out of it and replaced with the same number, leading to new debts for the people of that republic, and nothing was known of the galleon Santo Cristo at that date... The people of these islands were completely ruined and destroyed by the losses of the previous years and the galleons Santo Cristo de Burgos and San José, in which the wealthy residents assumed new debts with the merchants on the coast and China, having acquired large loans from them to send goods in these galleons." 91

The Oregon shipwreck, now thought to be the Santo Cristo de Burgos, was also transformative in what would become the state of Oregon. NehalemTillamook oral tradition suggests both cooperation and conflict with the survivors in what was almost surely their first direct, sustained interaction with non-Native people. ${ }^{92}$ Although brief, it seems to have resulted in an exchange of ideas, technologies, and even genetics as a small number of survivors married into the Indigenous communities of the area. We now know the names of the shipwrecked men who were likely part of this remarkable moment of contact, and we know enough of their backgrounds as a group to better appreciate the myriad outcomes of these unprecedented exchanges.

Students of Pacific Northwest history may be excused for immediately checking the list of names, for there are certain individuals who have a plausible link back to the galleon. As mentioned in a previous article, early French explorer Gabriel Franchère reported meeting in about 1811 an elderly man, "Soto," who attested that he was the son of a Spanish shipwreck survivor - among the earliest written evidence of a Spanish wreck found in Oregon 
history. ${ }^{93}$ Admittedly, the dates suggest that his father may have arrived on a later Spanish wreck, and the name could be a first name or a nickname, a Native gloss on a Spanish term, or so misspelled in transmission as to make it nearly unrecognizable. Still, among the Santo Cristo crew, we find the name Juan Francisco Sotelo and, far more compelling, Francisco de Zotto, whose name is most accurately transliterated into English as "Soto." 94 While these facts are conclusive of nothing in particular, they may be added to the list of intriguing but faint evidence linked to Spanish presence in the North Pacific.

Regrettably, the one other person who historically reported direct descent from the galleon survivors, the Native American Chief Kilchis of Tillamook Bay, is not easily traced back to the galleon on the basis of crew and passenger lists alone; even if his name was derived from a Spanish surname, he was widely reported to be a man of African descent and physiognomy. ${ }^{95}$ If so, he would likely have been the offspring of a slave - a population generally not reported in galleon passenger and crew lists. But it is unlikely that descent from a single slave more than a century before his birth would explain his appearance, and many later trading and exploring vessels along the coast had African slaves or crew aboard. ${ }^{96} \mathrm{~A}$ keystone figure of early north coast history and both a personification and proponent of interethnic collaboration - other avenues may need to be explored to determine whether it is possible to link Kilchis to the unfortunate crew or passengers of the Santo Cristo de Burgos, or other galleon that is ultimately determined to be Oregon's Beeswax wreck.

\section{NOTES}

The authors would like to thank the staff of the Archives of the Indies (Archivo General de Indias) in Seville, Spain; the National Archives of the Philippines (Pambansang Sinupan ng Pilipinas) in Manila; the Archivo General de la Nación of Mexico in Mexico City; and the Archivo General del Estado de San Luis Potosí. The authors extend our deepest gratitude to Esther González Pérez, professional and dedicated researcher at the Archives of the Indies, whose work documented the history of both the Santo Cristo de Burgos and the San Francisco Xavier. We also thank our translators Victoria Stapells and Trágora Traducciones of
Granada, Spain. For a full understanding of Don Bernardo Iñiguez del Bayo's biography we especially thank Dr. Alvaro Aragón Ruano of the University of the Basque Country in VitoriaGasteiz, Spain. For del Bayo's activities during his mayoralty in San Luis de Potosí, we are very grateful for the knowledge and assistance of Dr. María Isabel Monroy Castillo, professor at El Colegio de San Luis A.C. and the chronicler of San Luis de Potosí, Mexico. For photographs of the altarpiece in the Santiago Church, we thank Israel Trejo Muñiz of El Colegio de San Luis A.C.

1. Ministerio de Educación, Cultura y Deporte, Archivo Histórico Nacional, OM-Expe- 
dentillos, N.5800 (in González Research Report to La Follette, March 2017, 22-23); Genealogías Vascas: Zabalburu, http://www.euskalnet.net/ laviana/gen_bascas/zabalburu.htm (accessed April 29, 2018). In Spanish naming conventions, the father's paternal surname comes after the first name(s), followed by the mother's paternal surname. The person's regular last name is the father's paternal surname.

2. Dr. Alvaro Aragón Ruano, Department of Medieval, Early Modern and American History, University of the Basque Country, email message to La Follette, November 25, 2016.

3. Cesareo Fernandez Duro, Armada Española Vl, p. 96, quoted in Erik W. Dahlgren, The Discovery of the Hawaiian Islands (New York: AMS Press, 1977, reprint of Stockholm: Almquist \& Wiksells, 1916), 111. For notice of the galleon's disappearance in 1705, see Emma Helen Blair and James Alexander Robertson, eds. The Philippine Islands 1493-1898, vol. 44 1700-1736 (Cleveland, Ohio: Arthur H. Clark Company, 1906), 142.

4. See Scott S. Williams, Curt D. Peterson, Mitch Marken, and Richard Rogers, "The Beeswax Wreck of Nehalem: Archaeological Search for a Lost Manila Galleon," in this issue of the Oregon Historical Quarterly, 119:2 (Summer 2018): 192-209

5. William Lytle Schurz, The Manila Galleon (New York, NY: E.P. Dutton \& Co., 1939, 1959), 259.

6. Ministerio de Educación, Cultura y Deporte, Archivo General de Indias, Filipinas, 210, IM. 63 (in González Research Report to La Follette, October 2016, 7).

7. Dr. Alvaro Aragón Ruano, Department of Medieval, Early Modern and American History, University of the Basque Country, email message to La Follette, December 10, 2016.

8. Ministerio de Educación, Cultura y Deporte, Archivo General de Indias, Filipinas, 14, R.3, N.38 (in González Research Report to La Follette, March 2017, 2).

9. Chunming Wu, "A Summary on Shipwrecks of the Pre-contact Period and the Development of Regional Maritime Trade Network in East Asia," in Early Navigation in the Asia-Pacific Region: A Maritime Archaeological Perspective, ed. Chunming Wu (Singapore:
Springer Science + Business Media, 2016), 23; Schurz, The Manila Galleon, 23-24.

10. Ministerio de Educación, Cultura y Deporte, Archivo General de Indias, Filipinas, 26, R.1, N.3, IM 8-9 (in González Research Report to La Follette, March 2017, 6-7).

11. Ministerio de Educación, Cultura y Deporte, Archivo General de Indias, Filipinas, 210, IM. 588-589 (in González Research Report to La Follette, October 2016, 8-9).

12. Casimiro Diaz, O.S.A, "The Augustinians in the Philippines, 1670-1694," from Casimiro Diaz, Conquistas (Manila, 1890, 440-444 and 689-817), in Blair and Robertson, eds. The Philippine Islands 1493-1898, vol. 42, 309; Alexandre Coello de la Rosa, Jesuits at the Margins: Missions and Missionaries in the Marianas (1668-1769) (New York, NY and Abingdon, UK: Routledge/Taylor and Francis, 2016), 109-111

13. Diaz, "The Augustinians in the Philippines, 1670-1694," 309. This commentator mistakenly refers to the port of the 1692 return as Solsogón.

14. Juan de Zarzuela and others, Extracts from Jesuit Letters, Manila 1691 and 1694, as quoted in Blair and Robertson, eds., The Philippine Islands 1493-1898, vol. $41-$ 1691-1700, 36.

15. Ministerio de Educación, Cultura y Deporte, Archivo General de Indias, Filipinas, 26, R.7, N. 27 (in González Research Report to La Follette, January 2016, 32).

16. See, for example, Shirley Fish, The Manila-Acapulco Galleons: The Treasure Ships of the Pacific (Central Milton Keynes, UK, AuthorHouseUK, 2011), 408-409; and Arturo Giraldez, The Age of Trade: The Manila Galleons and the Dawn of the Global Economy (Lanham, Md., Rowman \& Littlefield, 2015), 120.

17. Percy Hill, Romantic episodes in old Manila: Church and state in the hands of a merry jester, Time (Manila, Philippines: Sugar News Press, 1925).

18. Walter Robb, from the Manuscripts of Percy A. Hill, Romance and Adventure in Old Manila (Manila: Philippine Education Co., 1928, rev'd 1935), v-ix.

19. Ibid., 183-85. Emphasis in original. 20. Ministerio de Educación, Cultura y 
Deporte, Archivo General de Indias, Filipinas, 24, R.9, N.45 (in González Research Report to La Follette, March 2016, 11).

21. Ministerio de Educación, Cultura y Deporte, Archivo General de Indias, Contaduria, 1245. F.170R, F.182R, F.184R (in González Research Report to La Follette, March 2016, 11-12).

22. Ministerio de Educación, Cultura y Deporte, Archivo General de Indias, Filipinas, 204, N.1, F.556R, F. 557V (in González Research Report to La Follette, October 2016, 11).

23. Ministerio de Educación, Cultura y Deporte, Archivo General de Indias, Filipinas 26, R.4, N.10, Doc.4 (in González Research Report to La Follette, May 2016, 3-4).

24. Diaz, "The Augustinians in the Philippines, 1670-1694," 303-304.

25. Ministerio de Educación, Cultura y Deporte, Archivo General de Indias, Filipinas, 26, R.4, N.10 (in González Research Report to La Follette, January 2016, 2).

26. Ministerio de Educación, Cultura y Deporte, Archivo General de Indias, Filipinas 26, R.4, N.10, Doc. 2 (in González Research Report to La Follette, May 2016, 2).

27. Ministerio de Educación, Cultura y Deporte, Archivo General de Indias, Filipinas 26, R.4, N.10, Doc. 3. (in González Research Report to La Follette, May 2016, 3).

28. Ministerio de Educación, Cultura y Deporte, Archivo General de Indias, Contaduria, 1248, F.461R-V, F.593V, F.707R-V (in González Research Report to La Follette, June 2015, 2-3).

29. Ministerio de Educación, Cultura y Deporte, Archivo General de Indias, Filipinas, 26, R.4, N.18, Doc. 2, IM. 12-20 (in González Research Report to La Follette, January 2016, 7-18).

30. Ministerio de Educación, Cultura y Deporte, Archivo General de Indias, Filipinas, 26, R.4, N.18, Doc. 1 (in González Research Report to La Follette, January 2016, 5-6).

31. Ministerio de Educación, Cultura y Deporte, Archivo General de Indias, Filipinas, 16, R.1, N.2 (in González Research Report to La Follette, October 2016, 4).

32. Ministerio de Educación, Cultura y Deporte, Archivo General de Indias, Filipinas, 16, R.1, N.2, IM. 27 (in González Research Report to La Follette, October 2016, 5).
33. Ministerio de Educación, Cultura y Deporte, Archivo General de Indias, Filipinas, 26, R.4, N.18, Doc. 2, IM 12-20 (in González Research Report to La Follette, January 2016, 7-8).

34. Ibid., IM. 251-67 (González Report, January 2016, 13-15).

35. Ibid., IM. 483-489; Ministerio de Educación, Cultura y Deporte, Archivo General de Indias, Filipinas, 26, R.4, N.18, Doc. 1 (in González Research Report to La Follette, January 2016, 7).

36. Ibid.; Esther González, email to La Follette, May 4, 2018 (in CLF-Gonzalez Emails re Pedro Flores, April-May 2018, 1)

37. Ministerio de Educación, Cultura y Deporte, Archivo General de Indias, Filipinas, 26, R.4, N.18, Doc. 2, IM. 876-892 and 840-841 (in González Report, January 2016, 20, 23).

38. Ibid., IM 926-930, González Report January 2016, 27.

39. Ministerio de Educación, Cultura y Deporte, Archivo General de Indias, Contaduria, 1248, F. 692R, F.649R; 1249, F. 237, F. 232 V (in González Research Report to La Follette, June 2015, 5-6).

40. Ministerio de Educación, Cultura y Deporte, Archivo General de Indias, Filipinas, 210, IM. 588-589 (in González Research Report to La Follette, October 2016, 8).

41. Ministerio de Educación, Cultura y Deporte, Archivo General de Indias, Filipinas, 26, R.4, N.18, Doc.5 (in Stapells \& González Research Report to La Follette, May 2016, 6).

42. Ministerio de Educación, Cultura y Deporte, Archivo General de Indias, Filipinas 26, R.4, N.18, Doc.2, IM. 38-67 (in Stapells \& González Research Report to La Follette, May $2016,1-3)$. We list only some of the extensive list of rules given to the galleon general to govern the 1693 voyage. The complete list, which contains additional technical, routerelated, and administrative rules, is found in the cited report.

43. For the list of passengers on the 1692 and 1693 voyages, see Ministerio de Educación, Cultura y Deporte, Archivo General de Indias, Filipinas 26, R.4, N.18, Doc.2, IM. 859-871 (in González Research Report to La Follette, January 2016, 21-22); and Esther González, email to La Follette, October 27, 2016. 
44. For the list of officers on the 1692 voyage, see Ministerio de Educación, Cultura y Deporte, Archivo General de Indias, Filipinas, 26, R.4, N.18, Doc. 1. IM 123-131 (in González Research Report to La Follette, January 2016, 10).

45. Giraldez, The Age of Trade: The Manila Galleons and the Dawn of the Global Economy, 140.

46. Fish, The Manila-Acapulco Galleons, 325-26.

47. Ministerio de Educación, Cultura y Deporte, Archivo General de Indias, Contratacion, 5447, N.2, R. 21 (in González Research Report to La Follette, December 2016, 15).

48. Archivo General de la Nación, Mexico. Archives of San Luis de Potosí, Block 1, December 24, 1689; and Block 2, February 19 to March 1, 1690 (in González Research Report to La Follette, December 2016, 2-4).

49. Archivo Histórico del Estado de San Luis Potosí "Lic. Antonio Rocha Cordero" (AHESLP), Collection of San Luis Potosí City Council (ASLP), Minutes of Council Meeting of December 6, 1688, Transcription by Dr. Maria Isabel Monroy Castillo, July 2017, Translation by Trágora Traducciones, August 2017.

50. Ibid. Minutes of Council Meeting of May 6, 169o. For further information and details about flooding in San Luis Potosí and the flood control works of Don Bernardo Iñiguez del Bayo, see Jesús Alfaro Saldaña, “Un paraje entre vetas y veneros Agua, ecoltura y devoción en la ciudad de San Luis Potosí en el siglo XVII" (Ph.D. diss., El Colegio de San Luis, A.C., October 2016), 15-20, 148-49, 209-216. Excerpts translated by Trágora Traducciones to La Follette, August 2017.

51. Ministerio de Educación, Cultura y Deporte, Archivo Histórico Nacional, OM-Caballeros Santiago, Exp. 400, IM. 4, IM. 7, IM. 10, IM. 11-14, IM. 66, IM. 77 (in González Research Report to La Follette, December 2016, 8-14, 9-10).

52. Ministerio de Educación, Cultura y Deporte, Archivo General de Indias, Filipinas 26, R.4, N.18, Doc.2, IM. 859-871 (in González Research Report to La Follette, January 2016, 10).

53. Fish, The Manila-Acapulco Galleons, 306-307.

54. Dr. Alvaro Aragón Ruano, Department of Medieval, Early Modern and American History, University of the Basque Country, email message to La Follette, March 16, 2017.

55. Fish, The Manila-Acapulco Galleons, 309-310.

56. Ibid., 311-12.

57. Ibid.

58. Ibid., 315.

59. Ibid., 317.

6o. Ibid., 315-16.

61. Ibid., 305; Ministerio de Educación, Cultura y Deporte, Archivo General de Indias, Filipinas 26, R.4, N.18, Doc.2, IM. 124-131 (in González Research Report to La Follette, March 2016, 14-15).

62. Fish, The Manila-Acapulco Galleons, 315-16.

63. Ibid.

64. Ibid, 322-23.

65. William A. Douglass, Basque Explorers in the Pacific Ocean (Reno, NV: University of Nevada Press, 2015), 127-73; Marciano R. De Borja, Basques in the Philippines (Reno, NV: University of Nevada Press, 2005), 58-63.

66. Fish, The Manila-Acapulco Galleons, 318.

67. Ibid., 319; Schurz, The Manila Galleon, 212.

68. Ibid, 320-22.

69. Ministerio de Educación, Cultura y Deporte, Archivo General de Indias, Contratacion, 5453, N. 85 (in La Follette-González Emails re González Research Report of January 2016, February 2016, 3).

70. Diaz, "The Augustinians in the Philippines, 1670-1694," 309-10.

71. See Ministerio de Educación, Cultura y Deporte, Archivo General de Indias, Indiferente, 203, N. 48 (in González Research Report to La Follette, March 2016, 18) for the earlier date; and for the later date, José S. Arcilla, "Slavery, Flogging and Other Moral Cases in 17th Century Philippines," Philippine Studies, 20:3 (Third Quarter 1972): 399.

72. Arcilla, "Slavery, Flogging and Other Moral Cases in 17th Century Philippines," 399-416.

73. Ministerio de Educación, Cultura y De- 
porte, Archivo General de Indias, Indiferente, 203, N.48 (in Stapells \& González Research Report to La Follette, May 2016, 5).

74. Ministerio de Educación, Cultura y Deporte, Archivo General de Indias, Filipinas 92, N.1, IM. 1675 (in González Research Report to La Follette, December 2016, 7).

75. Ibid.

76. Ministerio de Educación, Cultura y Deporte, Archivo General de Indias, Indiferente, 203, N. 48 (in González Research Report to La Follette, March 2016, 18).

77. Arcilla, "Slavery, Flogging and Other Moral Cases in 17th Century Philippines," 399-400 n2.

78. Ministerio de Educación, Cultura y Deporte, Archivo General de Indias, Filipinas, 82, N.15 (in La Follette-González Emails re González Research Report of January 2016, February 2016, 2).

79. Ministerio de Educación, Cultura y Deporte, Archivo General de Indias, Filipinas, 81, N.110 (in La Follette-González Emails re González Research Report of January 2016, February 2016, 3).

80. Ministerio de Educación, Cultura y Deporte, Archivo General de Indias, Indiferente 438, L.18, F.140V-141V (in La Follette-González emails regarding González Research Report of January 2016 and February 2016, 3-5).

81. Ministerio de Educación, Cultura y Deporte, Archivo General de Indias, Filipinas, 25, R.1, N.11 (in La Follette-González emails regarding González Research Report of January 2016 and February 2016, 3-5).

82. Ministerio de Educación, Cultura y Deporte, Archivo General de Indias, Filipinas, 194, N.16 (in González Research Report to La Follette, October 2016, 6).

83. Ministerio de Educación, Cultura y Deporte, Archivo General de Indias, Contratacion, 5450, N.51 (in La Follette-González Emails re González Research Report of January 2016, February 2016, 4).

84. Ministerio de Educación, Cultura y Deporte, Archivo General de Indias, Filipinas, 33, N.2, D.46/D.53 (in La Follette-González Emails re González Research Report of January 2016, February 2016, 5).
85. Ministerio de Educación, Cultura y Deporte, Archivo General de Indias, Escribania 1054A (in González research Report to La Follette, December 2016, 5).

86. Ibid.

87. Schurz, The Manila Galleon, 33, 272.

88. Arcilla, "Slavery, Flogging and Other Moral Cases in 17th Century Philippines," 400-402.

89. John Ordway, March 9, 1806 entry in The Journals of the Lewis and Clark Expedition, Gary Moulton ed. (Lincoln: University of Nebraska Press/University of NebraskaLincoln Libraries-Electronic Text Center, 2005), https://lewisandclarkjournals.unl.edu/ item/lc.jrn.1806-03-09\#lc.jrn.1806-03-09.03 (accessed May 9, 2018).

90. Diaz, "The Augustinians in the Philippines, 1670-1694," 307-09.

91. Ministerio de Educación, Cultura y Deporte, Archivo General de Indias, Filipinas, 210, IM. 448, IM. 449, IM. 451 (in González Research Report to La Follette, October 2016, 8).

92. See Cameron La Follette and Douglas Deur, "Views Across the Pacific: The Galleon Trade and Its Traces in Oregon," in this issue of the Oregon Historical Quarterly, 119:2 (Summer 2018): 160-91.

93. Ibid.

94. González Research Summaries re Soto-Sotelo Names, August 2017; Gabriel Franchère, Narrative of a Voyage to the Northwest Coast of America in the Years 1811, 1812, 1813, and 1814, J.V. Huntington, trans. (New York: Redfield, 1854), 112-13.

95. See Warren Vaughn (n.d.) Warren Vaughn's Diary, unpublished manuscript, collections of Tillamook Pioneer Museum. For a fuller discussion of Chief Kilchis and his possible links to the galleon, see LaFollette and Deur, "Views Across the Pacific: The Galleon Trade and Its Traces in Oregon," in this issue of the Oregon Historical Quarterly 119:2 (Summer 2018):160-191.

96. Darrell Millner, "The Death of Markus Lopius: Fact or Fantasy? First Documented Presence of a Black Man in Oregon, August 16, 1788," Trotter Institute Review 2:5 (June 1991): 19-22. 